\title{
Subjective measures of household resilience to climate variability and change: insights from a nationally representative survey of Tanzania
}

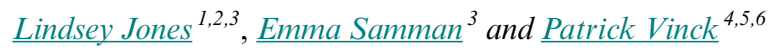

\begin{abstract}
Promoting household resilience to climate extremes has emerged as a key development priority. Yet tracking and evaluating resilience at this level remains a critical challenge. Most quantitative approaches rely on objective indicators and assessment frameworks, but these are not fully satisfactory. Much of the difficulty arises from a combination of conceptual ambiguities, challenges in selecting appropriate indicators, and in measuring the many intangible aspects that contribute to household resilience. More recently, subjective measures of resilience have been advocated in helping to overcome some of the limitations of traditional objective characterizations. However, few large-scale studies of quantitative subjective approaches to resilience measurement have been conducted.
\end{abstract}

In this study, we address this gap by exploring perceived levels of household resilience to climate extremes in Tanzania and the utility of standardized subjective methods for its assessment. A nationally representative cross-sectional survey involving 1294 individuals was carried out by mobile phone in June 2015 among randomly selected adult respondents aged 18 and above. Factors that are most associated with resilience-related capacities are having had advance knowledge of a previous flood, and to a lesser extent, believing flooding to be a serious community problem. Somewhat surprisingly, though a small number of weak relationships are apparent, most socio-demographic variables do not exhibit statistically significant differences with regards to perceived resilience-related capacities. These findings may challenge traditional assumptions about what factors characterize household resilience, offering a motivation for studying both subjective and objective perspectives, and understanding better their relationship to one another. If further validated, subjective measures may offer potential as both a complement and alternative to traditional objective methods of resilience measurement, each with their own merits and limitations.

Key Words: measurement; perceptions; resilience; subjective

\section{INTRODUCTION}

Resilience measurement has soared to the top of the development agenda (Frankenberger et al. 2014). As a result, researchers have proposed many frameworks and methods seeking to quantify the resilience of different social systems, whether at household, community, or national levels (Elasha et al. 2005, Twigg 2009, USAID 2009, Constas and Barrett 2013, Nguyen and James 2013, D'Errico and Giuseppe 2014). To date, most of these methods have focused on objective indicators and approaches, often centered on observing key socioeconomic variables and other types of capital that support people's livelihoods (Bahadur and Pichon 2017). More recently, the advantages of subjective approaches to measuring social systems have been advocated (Marshall and Marshall 2007, Jones and Tanner 2015, Lockwood et al. 2015, Maxwell et al. 2015, Béné et al. 2016a,b). These methods may offer the opportunity to address many weaknesses that beset traditional objective approaches, such as difficulties with indicator selection, a lack of attention to context specificity, and an inability to take people's knowledge of their own resilience into account.

However, few quantitative standardized assessments of subjective resilience have taken place (Marshall 2010). As such, little is known about their feasibility as a resilience measurement tool and how they compare with traditional objective methods, particularly when applied at scale. Accordingly, in this study, we propose a simple tool that seeks to measure 'subjective resilience' at a household level alongside numerous characteristics that often form part of objective assessments of resilience. We subsequently apply this tool to investigate the following research question: Is subjective resilience connected to particular socio-demographic characteristics of households, and if so, which ones?

In doing so, we seek to analyze the relationship between objective indicators generally used to signal resilience (or a lack thereof) and subjective assessments. If the relationship is weak, this has several potential implications. It could suggest that a more comprehensive assessment of resilience requires accounting for a broader range of objective characteristics, which may in turn suggest additional policy levers that could enhance resilience. Alternatively, it could suggest that intangible characteristics that are difficult to quantify shape resilience-related perceptions or indeed that subjective measures may not reflect overall resilience well. If the relationship is strong, then this could indicate that subjective measures, which require far fewer resources to administer, could be a useful proxy for (or used alongside) objective measures, for example, between rounds of an extended household survey; and that information about the relative influence of the objective measures on subjective resilience could enhance objective approaches, for example, by suggesting 'weights' that could be used in multidimensional indices.

To address the research question, we present results from a nationally representative survey focused on the subjective

\footnotetext{
${ }^{1}$ London School of Economics and Political Science, London, UK, ${ }^{2}$ Grantham Research Institute for Climate Change and the Environment, London, UK, ${ }^{3}$ Overseas Development Institute, London, UK, ${ }^{4}$ Harvard Humanitarian Initiative, Harvard University, Cambridge, USA, ${ }^{5}$ Harvard T. H. Chan School of Public Health, Harvard University, Cambridge, USA, ${ }^{6}$ Brigham and Women's Hospital, Boston, USA
} 
resilience of households to flood risk in Tanzania. To our knowledge, this is the first time that such a tool has been applied nationally. We propose survey questions to explore key resiliencerelated capacities, namely the capacities to prepare for, cope with, and adapt to future flood risk. We then assess how these capacities vary across socioeconomic characteristics to understand how subjective resilience is manifest across different household profiles. The choice of methods and wording of questions used in this study leans on earlier theoretical work by Jones and Tanner (2017), who explore the merits and limitations of assessing subjective resilience at the household level. It also draws on related methodological insights from earlier work by Marshall and Marshall (2007) and Maxwell et al. (2015) that use similar surveybased approaches to examine subjective resilience: the former proposes a method of subjectively measuring 'social resilience' in coastal communities in Australia, while the latter sets out principles and guidelines for the subjective measurement of resilience. Based on these exercises, we provide insights into the factors that are associated with subjective assessments of household resilience in Tanzania and compare these with traditional assumptions, those based largely on objective markers. Last, we present future avenues for the methodological refinement and testing of subjective approaches to household resilience.

\section{BACKGROUND AND CONTEXT}

Resilience has its roots in several different disciplinary fields, ranging from mechanics to ecology and psychology (see Alexander 2013 for a comprehensive historical overview). However, the term's more recent adoption across the sustainability sciences has bolstered its popularity amongst academic and policy communities alike. Indeed, resilience now forms a central pillar in many key international policy frameworks such as the United Nations' Agenda 2030, Sendai Framework for Disaster Risk Reduction, and Paris Agreement (United Nations $2015 a, b, c)$. Though the utility of a broad resilience framing has brought many benefits, it has also contributed to definitional and conceptual inconsistencies in its use (Olsson et al 2015). For example, early framings of resilience in describing social systems leant heavily on ecologic frameworks and revolved around the capacity to absorb change and disturbance in order to maintain core functions (Holling 1973, Walker et al. 1981, Odum 1985). Subsequent thinking within the field of social-ecological systems has challenged these frames when applying resilience to understand human responses to climate risk, encouraging greater recognition of the ability of social groups to adapt and change their core structure and functions (Berkes et al. 2002, Walker et al. 2004, 2006, Folke 2006, Bollettino et al. 2017). In some cases, it is argued that the complete transformation of a system may be a necessary component of a resilience process (Kates et al. 2012, Aldunce et al. 2015).

Nevertheless, there is broad agreement across disciplines that resilience comprises a range of evolving capacities and processes rather than constituting a static state (Maguire and Cartwright 2008). For example, in the context of community resilience to disaster risk, Norris et al. (2008) propose that resilience can be broken down into three core capacities: robustness (the strength of a system's resources); redundancy (the extent to which elements are substitutable in the event of disruption or degradation); and rapidity (how quickly the resource can be accessed and used). Béné et al. (2012) propose a framework consisting of the capacities to absorb, adapt, and transform. Many other such frameworks exist. However, agreement over the exact characterization of resilience is missing amongst the wider literature. These conceptual distinctions matter not only because the capacities needed to support them are different, but because they present a fundamentally different conceptualization of what a resilient system constitutes: "Such wide meanings may end up being contradictory as in the notion of 'restoring equilibrium and getting away from it by moving to a new state"' (Alexander 2013, as cited in Olsson et al. 2015:22).

As such, properties such as coping, adaptive and transformative capacities are often used in different ways and in different combinations when framing resilience (Bahadur and Pichon 2017). Indeed, they are frequently used interchangeably with resilience itself (Olsson et al. 2015). This lack of definitional and conceptual agreement presents challenges when seeking to track and measure resilience, but these difficulties notwithstanding, a wide range of measurement toolkits have emerged in recent years (Constas and Barrett 2013, FAO 2016, Frankenberger et al. 2014, Béné et al. 2016a).

Most efforts to measure climate resilience use objective criteria, socioeconomic indicators and processes that are considered to support a household's ability to deal with risk (Schipper and Langston 2015). "Objective," in this context, tends to denote framings of resilience that are based on external judgement and verification (Maxwell et al. 2015). Such approaches tend to be guided by an overarching conceptual framework, usually designed by technical experts or those external to the individual or household themselves, though sometimes these draw on qualitative inputs from intended communities or the piloting of survey instruments (Jones and Tanner 2017). Yet there is no universal acceptance on how resilience can and should be measured and hence a plethora of different objective frameworks and indicator lists exist, some contrasting markedly (Constas et al. 2016).

One widely used example is the United Nation's Food and Agriculture Organization (FAO) Resilience Index Measurement and Analysis model (RIMA), which combines socioeconomic variables from five dimensions: access to basic services; assets; adaptive capacity; social safety nets; and sensitivity to shock. These are then further broken down into dozens of individual indicators (D'Errico and Giuseppe 2014). Given that RIMA is centered around a predefined framework primarily based on wider resilience literature, has a list of expert-derived indicators for each characteristic, and relies on extensive surveys to collect externally verified information on household socioeconomic conditions (FAO 2016), the approach can be readily classified within the objective camp of measurement tools.

Objective measurement approaches such as RIMA have many strengths, including the ability to generate composite scores of resilience that can be readily compared across households. However, they also present several clear limitations. Most notably, they rely heavily on predefined resilience characteristics and standardized indicators. This renders it challenging to capture the context-specific nature of resilience: factors that make a coastal fisher in coastal Kenya resilient are unlikely to be the same as those for a pastoralist in the northeastern drylands of Kenya. In addition, objective approaches operate on the basis that resilience 
can be externally determined. Such approaches favor structural determinants at the expense of those based on human agency, which may be harder to understand and measure (Tanner et al. 2015). Crucially, they do not take into account people's knowledge of their own resilience and how they evaluate their lives. Thus, objective evaluations often require value judgements in generalizing the factors that are assumed to make others resilient and simplifying the complex nature of resilience across differing contexts. Ironically, these value judgements mean that many socalled "objective" approaches to resilience fall short on their own terms. Despite the limitations, objective approaches to resilience measurement remain the norm and dictate to a large degree our understanding of resilience processes at all scales.

Though yet to be fully explored in both conceptual and practical terms, subjective methods may offer an alternative and complementary approach to objective assessments of resilience (Marshall and Marshall 2007, Nguyen and James 2013, Jones and Tanner 2015, Maxwell et al. 2015, Béné et al. 2016a,b, Seara et al. 2016). Subjective evaluations are often used to gain bottom up and grounded insights into people's own understandings of resilience and its components. A significant body of literature has sought to understand subjective elements of household resilience (Twigg 2009, Buikstra et al. 2010, Gaillard 2010, Miller et al. 2010). The vast majority of this work is based on qualitative assessments, typically based on ethnographic case studies, interviews, and focus groups or participatory rural appraisals (PRA). Although these approaches provide tremendous value, particularly in allowing for depth and nuance, they are difficult to use as a basis for measuring resilience at scale or across contexts. We are concerned with a branch of subjective resilience consisting of standardized and quantifiable methods for evaluating perceived resilience.

At its simplest, subjective household resilience relates to an individual's cognitive and affective self-evaluation of the capabilities and capacities of their household, community, or any other social system to respond to risk (Jones and Tanner 2015). If care is taken to design suitable methodologies and survey questions, then a household's subjective resilience can, in theory, be readily quantified. Standardized subjective indicators can be measured in many ways. Perhaps the most evident and practical way of collecting standardized data is through large household surveys. Although open-ended questions might provide rich qualitative detail, closed-ended questions are more likely to enable the aggregation of scorings of resilience capacities and to facilitate comparison across social groups or time (OECD 2013). Indeed, insights and research from related fields, such as subjective wellbeing, risk perception, and psychological resilience suggest that that standardized subjective evaluations may help to capture many "softer" elements of resilience-related capacities; allow comparison across different contexts; and permit individuals' knowledge of the factors that contribute to their own resilience to be incorporated (Jones and Tanner 2015).

Despite its clear potential, relatively little is known about how people evaluate their own resilience using standardized subjective measures, nor whether factors traditionally associated with objective household resilience match those from subjective selfevaluations when assessed at scale. For this reason, in this article we seek insights into these research gaps.
We focus on a subset of resilience: household resilience to climate extremes. Multiple epistemological entry points for climate resilience exist, though most objective measurement frameworks break the concept down into a common series of distinct yet interrelated characteristics (Schipper and Langston 2015). Properties such as the capacity of a household to prepare for and reduce the impact of climate extremes (Bahadur et al. 2015); absorb and cope with disturbances; and modify and adapt structures in accordance with changing climatic stimuli (Jones et al. 2010) each commonly feature within the literature. However, myriad other properties and combinations thereof surface in each framework, and each also relies on different interpretations of resilience and its constituent processes and indicators (Schipper and Langston 2015). Identifying a common set of observable indicators that relate to a household's capacity to recover from climate extremes, or their ability to adapt to ever-increasing climate risk has so far proven difficult (Cutter et al. 2008). This is not least because many factors that contribute to resiliencerelated capacities are process driven and relatively intangible (Jones et al. 2010). For example, self-efficacy, social networks and cohesion, power and marginalization, and risk tolerance each help to determine a household's resilience (Adger et al. 2013, Béné et al. 2016b). For this reason, we believe that a subjective approach may have value in assessing resilience in this specific context.

\section{METHODOLOGY}

\section{Conceptual approach}

To explore the feasibility of assessing subjective resilience quantitatively and its links to objective characteristics that often feature in resilience measurement, we added a module of closeended questions to a nationally representative longitudinal telephone survey in Tanzania. To narrow the focus, we concentrated our survey questions on household-level disaster resilience, more specifically, resilience to flood risk. ${ }^{[1]}$ Our survey was based on a standardized and widely used framing of climate resilience (Aldunce et al. 2015, Bahadur et al. 2015), comprising of three core capacities.

The first capacity used in our subjective framework relates to a household's ability to prepare, more specifically, to anticipate and reduce the impact of climate variability and extremes through preparedness and planning, often by making use of relevant information and early warning (Bahadur et al. 2015). The second capacity relates to a household's ability to recover. This is primarily associated with its ability to absorb and cope with the impacts of climate variability and extremes, often through maintaining core functions or livelihood activities (Sundres and Birnbaum 2003, Folke et al. 2010). The third capacity relates to a household's ability to adapt, more specifically, to adjust, modify, or change its characteristics or actions to moderate potential damage or take advantage of new opportunities that arise (Jones et al. 2010).

We administered a single question to address each of these three capacities (Table 1). The three items are conceptually distinct, well understood by respondents, easy to use and, as we show below, were found to be relatively independent of one another. Each capacity question used a standardized unipolar Likert scale with four response alternatives. The approach builds on methods used to assess social resilience in individual communities (see Marshall 
Table 1. Resilience-related questions administered through the national survey.

\begin{tabular}{|c|c|c|}
\hline Component of interest & Survey question & Response items \\
\hline \multicolumn{3}{|c|}{$\begin{array}{l}\text { Enumerator introduction: "First we would like to ask you about what would happen if an extreme flood affected your community in the near future. By } \\
\text { extreme flood, I mean one that is likely to affect your household, or harm your dwelling, fields, or resources." }\end{array}$} \\
\hline Capacity to prepare & $\begin{array}{l}\text { If an extreme flood occurred, how likely is it that your } \\
\text { household would be well prepared in advance? }\end{array}$ & $\begin{array}{l}\text { 4-point scale: (1) Extremely likely; (2) Very likely; (3) Not very } \\
\text { likely; (4) Not at all likely. }\end{array}$ \\
\hline Capacity to recovery & $\begin{array}{l}\text { If an extreme flood occurred, how likely is it that your } \\
\text { household could recover fully within } 6 \text { months? }\end{array}$ & $\begin{array}{l}\text { 4-point scale: (1) Extremely likely; (2) Very likely; (3) Not very } \\
\text { likely; (4) Not at all likely. }\end{array}$ \\
\hline Capacity to adapt & $\begin{array}{l}\text { If extreme flooding were to become more frequent, how likely } \\
\text { is it that your household could change its source of income } \\
\text { and/or livelihood, if needed? }\end{array}$ & $\begin{array}{l}\text { 4-point scale: (1) Extremely likely; (2) Very likely; (3) Not very } \\
\text { likely; (4) Not at all likely. }\end{array}$ \\
\hline \multicolumn{3}{|c|}{ Enumerator introduction: "Finally, I'm going to ask you about your household's experience of flooding over the last two years." } \\
\hline Severity & $\begin{array}{l}\text { In the last two years, how serious a problem has flooding been } \\
\text { to your household? } \\
\text { In the last two years, how serious a problem has flooding been } \\
\text { to your community? }\end{array}$ & $\begin{array}{l}\text { 4-point scale: (1) The most serious problem; (2) One of the serious } \\
\text { problems of many; (3) A minor problem; (4) Not at all a problem } \\
\text { 4-point scale: (1) The most serious problem; (2) One of the serious } \\
\text { problems of many; (3) A minor problem; (4) Not at all a problem }\end{array}$ \\
\hline Early warning & $\begin{array}{l}\text { Please think about the last extreme flood that affected your } \\
\text { household. Did you know about it in advance? }\end{array}$ & $\begin{array}{l}\text { 3-point scale: (1) No; (2) Yes; (3) Household not affected by a } \\
\text { flood in the last two years }\end{array}$ \\
\hline
\end{tabular}

and Marshall 2007, Nguyen and James 2013, Seara et al. 2016), as well as similar approaches used to evaluate subjective capacities in related fields such as subjective well-being (OECD 2013), risk perception (Mills et al. 2016), and psychological resilience (Connor and Davidson 2003).

Although each capacity question is administered via a single-item, as per the approach adopted by Béné et al. $(2016 a, b)^{[2]}$, we see resilience as multidimensional; therefore it is not amenable to being measured via a stand-alone question. It is important to underscore that none of the three capacity questions should be interpreted as representing resilience overall; it is for this reason that we refer to them as "resilience-related capacities" throughout. Instead they should be considered to represent several core functions deemed necessary to support household resilience.

This study is primarily exploratory. Although we seek to test a research question, given this is a novel area of academic interest with few other studies applied at the national level, we are primarily interested in understanding the dynamics of subjective resilience and working toward further validation and refinement of the tools applied. We hope that future work can build on these research insights and seek more confirmatory and experimental approaches, including the use of scales with numerous, replicative items (see Jones 2017).

\section{Survey instrument}

The questions were administered via a nationally representative survey in Tanzania, namely the Sauti za Wananchi (Voices of Citizens) longitudinal survey managed by the Tanzanian nongovernmental organization Twaweza and surveying company Ipsos Synovate. The survey is composed of two phases. First, a baseline survey was carried out through traditional face-to-face interviews using a multistage stratified sampling approach (Twaweza 2013). A sample of 2000 households in 200 enumeration areas were surveyed in October 2012, using a sampling frame designed to be representative of the Tanzanian population aged 18 years and older based on the 2012 Tanzania Population and Housing Census (NBS 2013). At this point, all households were given a mobile phone and solar charger. The second phase consists of a series of mobile telephone surveys with the same sampled households as in the baseline (Details of surveys to date and the datasets are available at http://www.twaweza.org/ go/sauti-za-wananchi-english).

In the round associated with this paper's results, the survey focused on assessments of political leadership. Resilience-related questions were included in an add-on module. ${ }^{[3]}$ Respondents were contacted in July 2015 to take part in the survey through a computer aided telephonic interview (CATI) operated via an Ipsos Synovate managed call center in Dar es Salaam. A total of 1335 respondents out of the potential 2000 from the initial baseline completed this wave of the survey. ${ }^{[4]}$ Questions were administered in Swahili and English, with a small financial incentive provided to respondents for their participation (US\$0.5 mobile airtime credit). For full details of the sampling procedure, weighting, and data collection see (Twaweza [date unknown]). For 1334 of the respondents, a wide array of socio-demographic data from the 2012 baseline are available, as well as responses to the resilience questions listed above. ${ }^{[5]}$ We removed an additional 40 of these respondents from the dataset because it was not certain that the same person replied as in the baseline, leaving 1294 matched observations. ${ }^{[6]}$

In the analysis, we describe the characteristics of our sample and then present descriptive statistics on their reported resiliencerelated capacities, followed by multivariate analysis. Because the ordinal variables measuring resilience-related capacities are not normally distributed, we test the equality of proportions rather than means. ${ }^{[7]}$ In the multivariate analysis, we used ordinal logistic models in which we regressed resilience-related scores - the extent to which respondents reported it was likely they could prepare for, adapt to, or transform their livelihoods in the event of severe flooding - on a range of objective controls to test whether these individual variables were independently able to predict levels of perceived household resilience. Independent variables included the age, gender, education, and household size of respondents, whether they were occupied in farming and whether they lived in an urban or rural area; ${ }^{[8]}$ the wealth quintile of the household (using an asset index); and whether the household had previous experience of a flood, believed flooding to be a serious problem 
Fig. 1. Subjective self-evaluations of resilience-related capacities to extreme flooding in Tanzania.

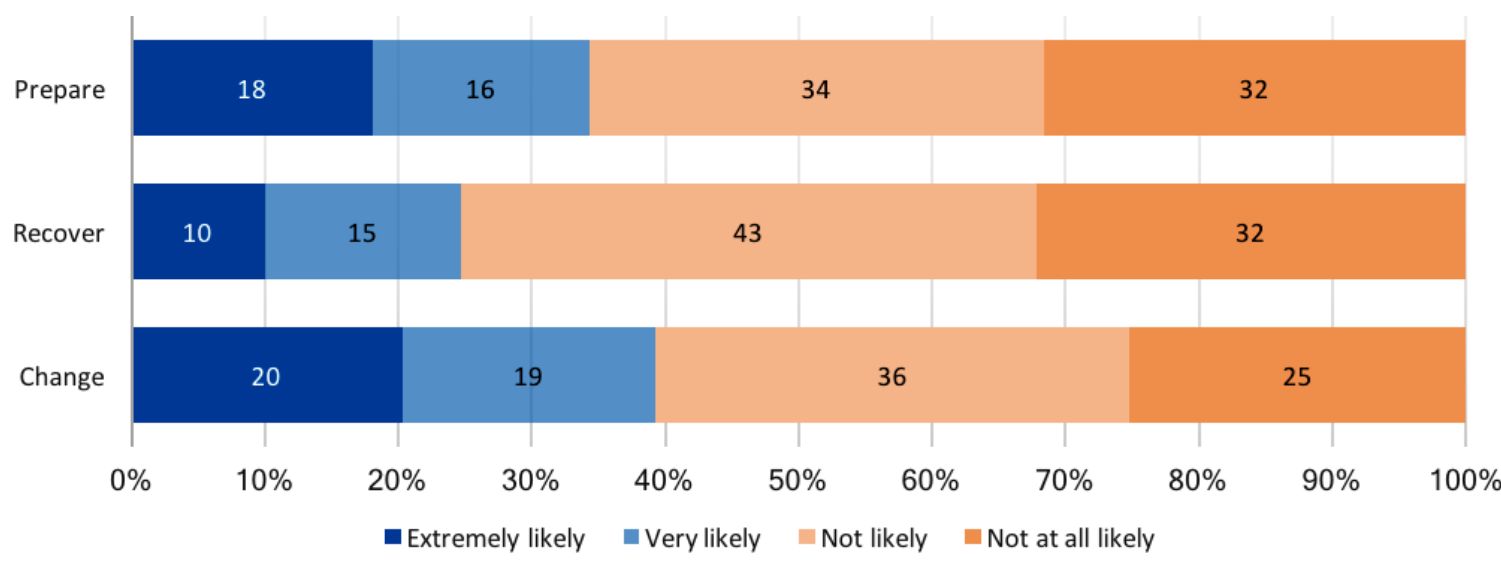

for their community, and whether they had known about the last flood that affected them (within the previous two years) in advance. ${ }^{[9]}$ Given the regressors are the same across these models, we use a seemingly unrelated estimation technique to account for the correlation in the error terms (Weesie 1999, StataCorp 2013).

\section{Sample characteristics}

Our respondents to the survey were primarily household heads $(98 \%)$, the majority of whom were male $(57 \%) .{ }^{[10]}$ They were primarily rural (65\%) and occupied in farming (also 65\%). We defined household wealth status according to an asset index that places households into quintiles. ${ }^{[11]}$ Some $93 \%$ of households in the poorest asset quintile were in rural areas compared with about $16 \%$ of households in the richest asset quintile. Most respondents had a completed primary education $(61 \%)$ whereas around $13 \%$ had at least some secondary education, 3\% had a higher education, and just under $10 \%$ had no formal education. The mean age of respondents in our sample was 40 years, 37 for females and 42 for men, with a range of between 18 and 89 years old.

\section{RESULTS}

\section{Experience of floods and perception of risk}

Respondents were asked to report their previous experience of extreme flooding (see Table A1.1. ${ }^{[12]}$ ). Overall, 32\% reported having experienced at least one such event in the past two years. Among respondents with recent experience of severe flooding, $26 \%$ reported having had advance warning before the flood. Respondents were also asked how serious a problem extreme flooding was, independently of whether they had recently experienced a flood. Most did not report flooding as a serious concern either for their households $(86 \%)$ or for their communities (71\%; Fig. A1.1). However, respondents from households that had experienced a flood in the previous two years were far more likely to perceive flooding as problematic; close to $40 \%$ of the exposed population reported flooding as a serious problem or the most serious problem for their household and over half $(54 \%)$ reported it as serious or most serious for their community, compared with $2 \%$ and $17 \%$ of those who had not been exposed to a recent flood, respectively. This is in line with previous studies finding experience of past flooding as a strong contributing factor to risk perception (Mills et al. 2016). There were no other sociodemographic cleavages, except that respondents from asset poor households were more likely to believe flooding was serious for their communities.

Among respondents with recent flood exposure, those who had early warning of that flood were more likely to perceive it as a serious problem, both for their households and their communities, than those who had not (Fig. A1.2). Some $57 \%$ and $67 \%$ of the population who had received advance warning of a previous flood perceived flooding to be a serious threat to their households and communities respectively, compared with $33 \%$ and $49 \%$ of those that did not have an early warning.

\section{Perceptions of resilience and association with experience and perception of risk}

Respondents assessed their perceived capacities to prepare for, recover from, and change their livelihood strategy in response to an extreme flood event. Most respondents reported a low perceived ability to prepare, recover, or change. Just one-third of the population reported that their households would be prepared in the event of a flood, one-quarter felt their households were capable of recovering fully within a six-month period, and 4 in 10 people felt their households could change their source of income/livelihood, if needed (Fig. 1).

Association between dimensions of resilience-related capacities Examination of the relationship between the three capacities reveals that they are only moderately associated. For example, $53 \%$ of respondents who said they were likely to be prepared also said they were likely to recover, compared to just $10 \%$ of those who were unlikely to be prepared. Odd ratios show that respondents who were likely to prepare were five times more likely to recover compared to respondents unlikely to prepare (Fig. A1.3). Nevertheless, when using the four-point Likert scale, the rank order correlations among these three types of capacity were all less than 0.5 (Fig. A1.4). The highest correlation $(0.45)$ is between reporting being able to prepare for a flood and to recover from it; while the lowest $(0.25)$ is between being able to recover from a flood and to change one's way of life in response to it. We also constructed binary variables (likely/unlikely) and found very similar correlations. 
Fig. 2. Relationships between resilience-related capacities and socioeconomic variables.

a) Gender \& HH resilience-related capacities

\begin{tabular}{|c|c|c|c|}
\hline \multirow{2}{*}{$\begin{array}{l}\text { 总 } \\
\text { 愙 } \\
\text { 空 }\end{array}$} & Male & 39 & 61 \\
\hline & Female & 39 & 61 \\
\hline \multirow{2}{*}{ 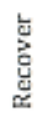 } & Male & 25 & 75 \\
\hline & Female & 24 & 76 \\
\hline \multirow{2}{*}{$\begin{array}{l}\text { 䓵 } \\
\text { 总 }\end{array}$} & Male & 34 & 66 \\
\hline & Female & 35 & 65 \\
\hline
\end{tabular}

c) Rural/urban and HH resillience-related capacities

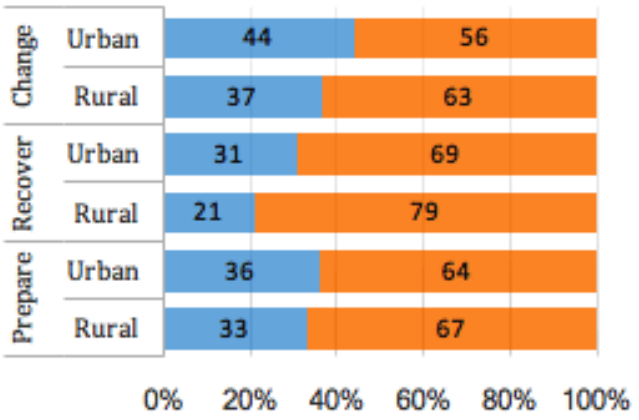

b) Occupation in farming \& HH resilience-related capacities

\begin{tabular}{|c|c|c|c|}
\hline \multirow{2}{*}{$\begin{array}{l}\text { 总 } \\
\text { 窇 } \\
\text { 窇 }\end{array}$} & Farmer & 38 & 62 \\
\hline & Nonfarmer & 42 & 58 \\
\hline \multirow{2}{*}{ 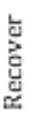 } & Farmer & 22 & 78 \\
\hline & Nonfarmer & 29 & 71 \\
\hline \multirow{2}{*}{ 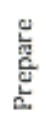 } & Farmer & 34 & 66 \\
\hline & Nonfarmer & 35 & 65 \\
\hline
\end{tabular}

d) Education and HH resilience-related capacities

\begin{tabular}{|c|c|c|c|}
\hline \multirow{2}{*}{$\begin{array}{l}\text { 总 } \\
\text { 突 }\end{array}$} & \multirow{2}{*}{$\begin{array}{r}\text { Primary } \\
\text { No Primary }\end{array}$} & 41 & 59 \\
\hline & & 33 & 67 \\
\hline \multirow{2}{*}{ 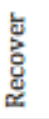 } & Primary & 26 & 74 \\
\hline & No Primary & 20 & 80 \\
\hline \multirow{2}{*}{ 愛 } & Primary & 36 & 64 \\
\hline & No Primary & 27 & 73 \\
\hline
\end{tabular}

e) Wealth quintile and resilience-related capacities

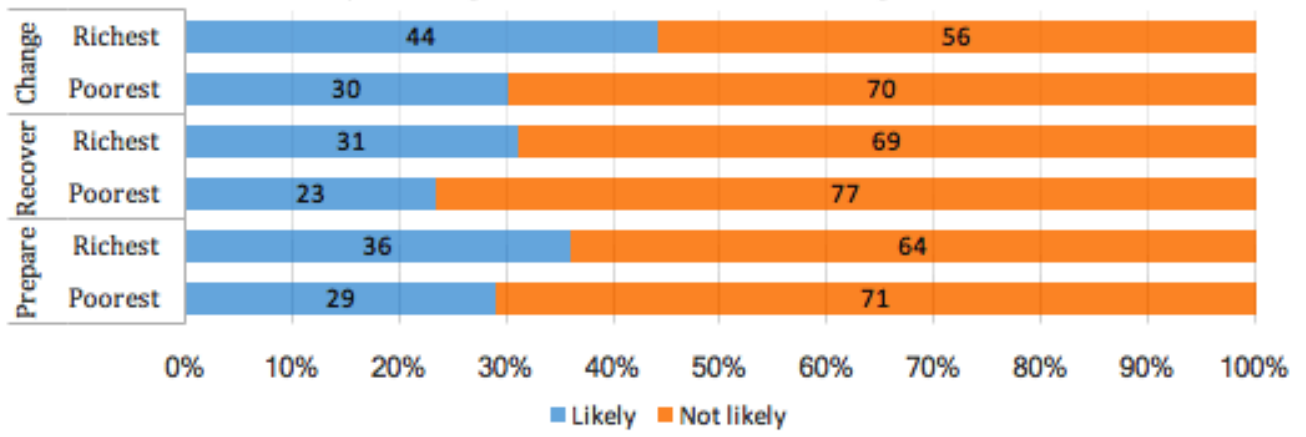

We examined whether these items could be combined to form an index of a latent construct of resilience. The three items did not meet the established threshold for internal consistency (Cronbach's alpha is 0.62 , below the commonly accepted threshold of 0.7 ). However, item selection was also tested by principal components analysis that showed that the three items loaded strongly onto one variable with an eigenvalue higher than 1 (the threshold recommended by Kaiser's rule; Fig. A1.5). This gives some support for constructing an index of perceptions of resilience; however, in this paper we focus on analysis of the three components individually to obtain more insights into factors that are associated (or not) with each. We defer discussion of the value of a composite index for future work.
Factors associated with perceptions of resilience

We analyzed the three resilience-related capacities across a range of variables of interest (Figs. 2 and 3, Tables A1.1-A1.6). Male and female respondents provide very similar responses across the board, though this may not be surprising given that the survey deliberately asks respondents to rate household-level capacities, not individual ones. Fewer farmers than nonfarmers (and people in rural versus urban areas) report an ability to recover fully from an extreme flood event within six months. Responses are very similar across occupations and rural/urban zone with respect to the perceived capacity to prepare for and adapt, though a lower share of farmers and rural residents report that it is "extremely likely" that they would adapt to an extreme flood. 
Fig. 3. Relationships between early warning and resilience-related capacities.

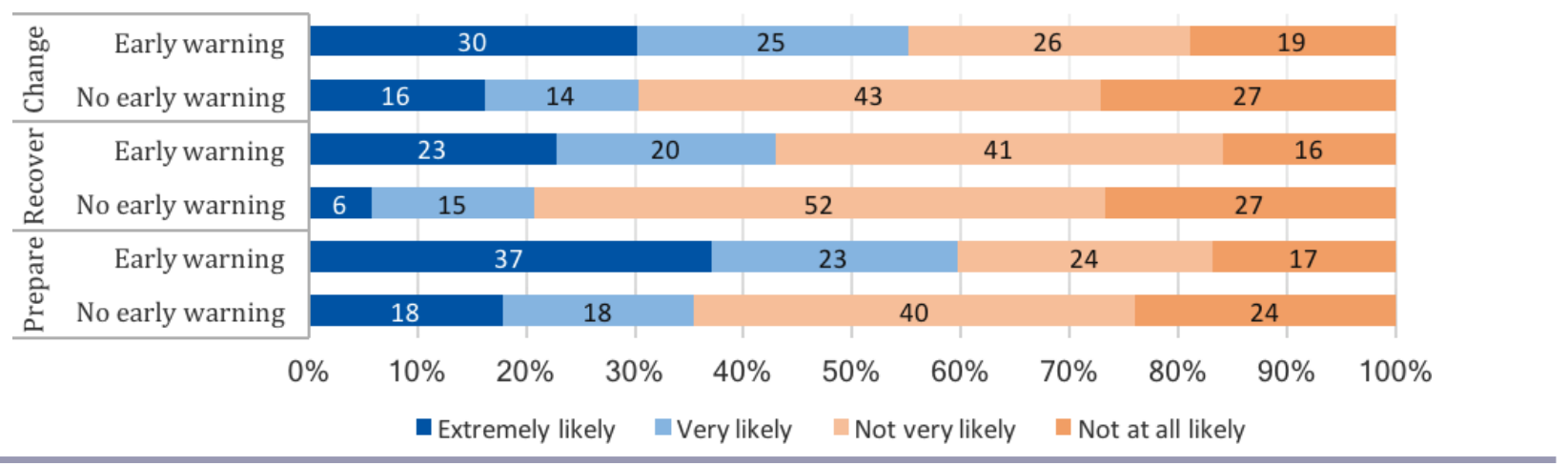

Education is positively associated with the perceived capacity to recover from a flood but not with the capacity to be prepared or to adapt on average. However, far fewer respondents with a higher education believe it is "not at all likely" they would be prepared for or able to adapt to an extreme flood, relative to those with less education. Wealth quintile is not linked with perceived preparedness but a higher share of respondents in wealthier quintiles report that they could recover and change their livelihoods in response to an extreme flood event (Fig. 3).

Self-reported capacities differ more markedly in line with the recent experience of flooding. Indeed, a higher share of those who had an experience of extreme flooding in the two years prior to the survey reported that they would be likely or very likely to prepare and to recover (but not to change their livelihood). For example, one-quarter of the population with recent flood exposure reported it was "not at all likely" they would be prepared for or recover fully from extreme flooding within a six-month period, compared with over one-third (35-36\%) of those who had not experienced a flood. This suggests either that perceptions are influenced by experience of flooding, which in turn builds confidence in their ability to deal with flood risk, or that floods have been experienced in areas where households have higher resilience-related capacities.

Perhaps of most interest, having had early warning is consistently and strongly associated with all three capacities (Fig. 3). For example, $45 \%$ of those with early warning of a previous flood reported it unlikely that they would be prepared for extreme flooding, compared with $70 \%$ of those who had not had such a warning. For the capacity to recover, the figures were $57 \%$ and $79 \%$, respectively, while for the capacity to adapt, they were $40 \%$ and $64 \%$. In other words, the differences associated with early warning ranged between 22 and 25 percentage points. The most common source of early warning is through local and national radio $(75 \%)$ with television $(18 \%)$ and newspapers $(3 \%)$ being far less common. It could be that respondents in more resilient households are more likely to obtain information regarding upcoming extreme weather events, or conversely, that the receipt of such information improves household resilience (indeed both mechanisms could be in play, or an unobserved trait could influence both aspects). But given that the provision of early warning information is such an important policy lever, greater exploration of the hypothesis that making information about flooding available improves resilience-related capacities is warranted, in line with similar research on risk perceptions of flooding (Miceli et al. 2008).

\section{Multivariate analysis}

To understand better factors associated with the perceived capacity to be prepared for, to recover from, and to adapt to extreme flooding, and how they relate to one another, we conducted seemingly unrelated regressions using ordinal logistic models with the capacity variables as the dependent variables. Across all the models, it is immediately apparent that the regressors have negligible explanatory power, explaining at most $2 \%$ of variation in these capacities. ${ }^{[13]}$ Very few variables display a statistically significant association with any of the capacities (Table A1.7).

Across all the regressions, the only consistent explanator was not having known about the previous flood; in all cases, this was associated with lower reported capacities and the coefficients were strongly statistically significant. Examination of the marginal effects reveals the extent of these gaps (Fig. 4). Interestingly, in all cases, predicted probabilities for respondents who had not experienced a flood or had experienced a flood but did not know about it in advance were very similar (the differences were not statistically significant). Meanwhile respondents who had had advance knowledge of a previous flood were more likely to report preparedness and the capacities to recover and adapt.

Other positive (and statistically significant) relationships were found between having a higher education and both preparedness and the capacity to recover; between household size and the capacity to recover; and between wealth quintile and the capacity to adapt (Table A1.7). The effect of age is negatively associated with reporting preparedness until the age of 35 and positive thereafter. None of the covariates variables had an equivalent effect to having known about a previous flood, with the sole exception of being in the top wealth quintile on the perceived capacity to adapt.

\section{DISCUSSION}

We have proposed a tool to explore perceived levels of household resilience to climate extremes in Tanzania, and how objective characteristics map onto these assessments. We seek to contribute to a nascent body of literature on the measurement of resiliencerelated capacities. The results of the nationally representative survey point to a logical association between the previous 
Fig. 4. Predicted probability of capacity to prepare, recover, and adapt to an extreme flood event, based on early warning of that event. Marginal effects computed on the basis of the separate ordinal logistic regressions.

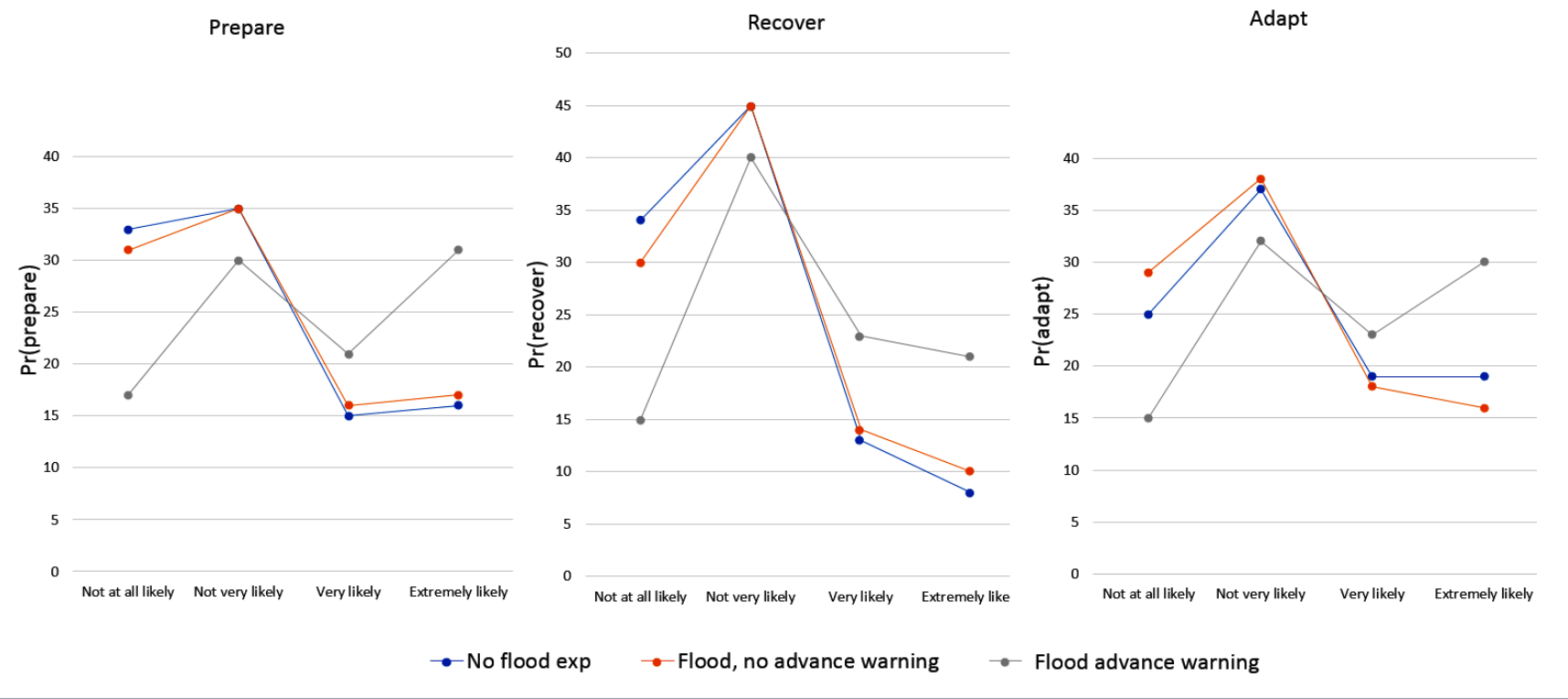

experience of flooding and perceived severe risk associated with flooding at the household and community levels. Respondents who had received advanced warning of flooding in the past were more likely to perceive it as a serious problem, both for their households and their communities, than those who had not. This association could be a function of the severity of the previous flood-more efforts are likely to be taken to warn people of more extreme events in areas where floods are more severe - but it could also reflect that people who believe flooding is serious are more likely to seek out advance warning.

The survey results also suggest that low resilience-related capacities appear to be a concern in Tanzania where most households reported limited capacities to be prepared for, respond to, or change their livelihood strategies in response to an extreme flood. The scores across the three capacities were fairly similar; around one-third of respondents felt they were likely to be prepared in the event of a flood, one-quarter felt they could recover fully within six months, and 4 in 10 felt they could change their livelihood if needed. It is intriguing, however, that a greater proportion of respondents felt able to change their livelihood strategies than to prepare for, and to a much greater extent, cope with, an extreme flood. This may suggest that perceived levels of adaptive capacity are higher relative to the other two resilience capacities. The share is somewhat lower among people with less education and fewer assets (though only the wealth differences are statistically significant); however, fully $30 \%$ of respondents without education and one-third of those from households in the poorest asset quintile felt that they would be able to adapt. The results could, in part, be explained by increasing levels of livelihood diversity and flexibility with regards to sources of income and livelihood among Tanzanians (Hedges et al. 2016). In future work, it would be advisable to probe understandings of the adaptive capacity-related question, including whether people associate it with longer term change rather than short-term coping strategies, and the sorts of livelihood strategies people feel they can adopt.

The correlations among responses to the three questions were positive but lower than expected (less than 0.5), reflecting considerable diversity among households with respect to the three capacities. These moderate correlations (and the relatively low Cronbach's alpha of 0.62) also point to a lack of internal consistency, though principal components analysis showed that they loaded strongly onto a single factor. To better understand these three components, we treat them separately and defer the question of whether an index of resilience-related capacities could be useful to follow-up research.

What is perhaps most interesting is that though a small number of weak relationships are apparent, most socio-demographic variables do not exhibit statistically significant differences with regards to perceived resilience-related capacities, e.g., age, education, occupation, wealth status, and place of residence. This is important given that these factors feature in objective assessments and are typically assumed to be strongly associated with household resilience (see FAO 2016). In this, our findings align with those of Béné et al. (2016b) who find that among coastal fishing communities in Ghana, Fiji, Vietnam, and Sri Lanka, none of the demographic characteristics that they analyzed apart from assets had a demonstrable impact on subjective resilience, which they characterize as "individual perception and selfconfidence about their own ability to handle future events" (Béné et al. 2016b:21). It is perhaps notable that the strongest relationship we find among the demographic variables is between belonging to the upper wealth quintile and the perceived capacity to adapt. Moreover, our data show that relationships between socioeconomic variables and perceived resilience-related capacities are broadly similar among respondents who had recently experienced a flood, i.e., in the previous two years, and those that had not. 
Several areas are worth considering. On the one hand, these results could indicate that traditionally measured objective characteristics do not have a strong influence on individual perceptions of a household's ability to prepare, recover from, and adapt to climate risk. If replicated in other areas and through different means, this could in turn cast doubt on the suitability of objective characteristics as effective measures of household resilience overall (Levine 2014). On the other hand, a subjective approach to assessing household resilience may be a poor reflection of overall resilience: those with a low resilience may perceive themselves to be more resilient than they are, and vice versa.

Part of the difficulty in establishing which of these two positions is applicable is that there is no present means of validating one or the other. Both objective and subjective measures are approximations of a somewhat intangible, contextual, and evolving concept. This is similar in many ways to difficulties faced in defining and measuring concepts such as well-being, risk perception, and happiness (Deeming 2013). More needs to be done to examine the effects of different characterizations and framings of resilience within subjective survey modules so as to establish the robustness of comparative subjective scores. Additional considerations relate to the validity of the survey questions themselves, response structures, or the means of administering the survey by telephone (see Leo et al. 2015). Each may have affected the results of the survey and explain several of the counterintuitive findings. In addition, several of the variables focus on individual characteristics such as gender and education, making it difficult to differentiate between personal and household-level dynamics. To confront this subjective-objective mismatch, further qualitative work is recommended, to seek to establish which factors are more closely associated with community-wide assessments of preparation, recovery, and adaptation. Ultimately a long-term cohort study and natural experiment may be needed to effectively assess how well proposed measures of resilience, objective and subjective, measure actual resilience as demonstrated in the face of natural disasters.

It is striking, however, that this study finds that the strongest and most consistent relationship is with having had advance knowledge (presumably through some form of early warning system) of a flood's occurrence. The mechanisms are unclear and will warrant further exploration, but these variables suggest potentially valuable policy levers to enhance resilience through the provision of early warning and (to a lesser extent) by raising awareness about the potential severity of extreme flooding. Most importantly, the results provide some confidence to the considerable investments that have gone into early warning systems (EWS) as a means of supporting disaster risk reduction and resilience regionally and globally (Sorensen 2000, Basher 2006, Miceli et al. 2008). In particular, our findings underscore the centrality of radio in sharing weather-related information and warnings among East African communities.

We believe that our study also demonstrates the ability to use subjective measures of household resilience at scale, i.e., in a national survey, and to administer them using mobile phone technology, which confers notable advantages in terms of cost, frequency, and accessibility. The latter characteristic could be especially useful following a severe climatic shock.
It remains to be seen whether standardized scaled-up subjective approaches to resilience measurement can be used for crosstemporal and cross-cultural comparison. Although the former may be relatively straightforward, particularly if panel data are in use, the latter may require considerable thought and validation, both empirical and qualitative, to assess whether internalized notions of resilience mean the same thing across contexts, and if data collected at such scales are meaningful. However, in related work on subjective well-being, there is some, albeit mixed, evidence that cross-cultural measures are meaningful and valid (Jorn and Ryan 2014). If this holds for resilience, then subjective tools may offer some promise in tracing progress in resiliencebuilding over time and across contexts at local, national, and international levels.

\section{CONCLUSION}

The research presented in this paper represents one of the first efforts to collect nationally representative data on subjective aspects of resilience, namely perceptions of the capacity to prepare for, to recover from, and to adapt to an extreme flooding event. We also explore the potential for collecting such data via a mobile phone survey, taking advantage of an ongoing panel survey in Tanzania.

We find that while some factors traditionally associated with household resilience such as asset wealth are strongly associated with subjective assessments, others like levels of education, livelihood types, and degree of urbanization have weak and in some cases nonexistent statistical relationships to subjective resilience. However, receipt of advance knowledge of flood risk appears to be one of the strongest predictors of a household's perceived ability to deal with risk, with notable policy relevance. Above all, the research underlines the need for greater recognition of subjective elements of resilience, not only with regard to how psychological and socio-cultural factors may contribute to a household's ability to deal with climate risk, but also factoring in people's knowledge of their own resilience.

While the work we have presented suggests the approach we adopt is potentially useful, it is necessarily far from indicative or comprehensive at this stage. Further testing of this instrument and of other efforts to measure perceptions of resilience, alongside objective indicators, is warranted. This includes examining the implications of different definitions and framings of resilience on subjective scores; exploring different multi-item scales to measure subjective resilience; assessing how subjective resilience changes over time and across contexts; and establishing the effects of various cognitive biases. This research also draws attention to a more acute issue facing the study of resilience and resilience-related capacities, namely the lack of a gold standard of what constitutes resilience against which attempts at its measurement could be triangulated. That such a standard might itself be context specific adds yet an additional layer of complexity to this multilayered, yet vitally important, concept.

${ }^{[1]}$ Flood risk was chosen specifically given that it is a rapid onset shock that is easily communicable and defined in a survey context. In addition, flooding is a hazard that affects large areas of Tanzania with recovery typically occurring immediately after the 
cessation of a flood. It is worth noting that extensive flooding had occurred two weeks prior to the survey (May 2015) affecting areas of Dar es Salaam, Arusha, Kilimanjaro, Tanga, and Kagera. ${ }^{[2]}$ Indeed, Béné et al. $(2016 a, b)$ apply a single-item question to represent household resilience in its entirety. Here we choose to disaggregate further by examining distinct resilience-related capacities.

[3] Financial support was provided by the Global Resilience Partnership.

${ }^{[4]}$ The individuals and households who participated in this round were assigned "weights" to adjust for nonresponse and design error (Twaweza [date unknown]). The resulting data are intended to be representative of the adult population of mainland Tanzania not including Zanzibar (Twaweza 2013).

${ }^{[5]}$ For one respondent, baseline information was not available and so the corresponding data were removed.

${ }^{[6]}$ Because the Sauti za Wanachi survey is administered by phone, each time it is conducted, the respondent is asked to give their name. In this round, 8 respondents gave a different name than in the baseline and 32 respondents did not provide a name. We removed all 40 responses.

${ }^{[7]}$ The Wilcoxon-Mann Whitney statistic (for two groups) and the Kruskal-Wallis test (for more than two groups) were selected as the nonparametric test best suited to ordinal responses (following Marusteri and Bacarea 2010), although it does not permit incorporating the complex stratified survey design. Nonparametric tests do not make assumptions about the underlying distribution of a variable but are less powerful than parametric tests.

${ }^{[8]}$ The sample size is not large enough to permit analysis by subregion apart from by urban-rural zone (Sana Jaffers, personal communication).

${ }^{[9]}$ The belief that flooding posed a problem to the community and the household were highly correlated; we chose to include the former because the bivariate analysis revealed stronger relationships with the resilience-related capacities. We restricted the focus to flooding occurring in the last two years to ensure a relatively recent and consistent frame of reference.

${ }^{[10]}$ Because almost all respondents were household heads, we focused our analysis on the gender of the respondent rather than female versus male headship.

${ }^{[11]}$ The wealth index was generated by principal components analysis using the following household assets: radio, mobile phone, fridge, TV, sofa set, electric/gas cooker, motor vehicle, livestock, and water pump (Twaweza, personal communication).

${ }^{[12]}$ The statistics presented here are for the population, i.e., they incorporate the complex sampling design, while Appendix 1 presents the unweighted data and test statistics for these data. In practice, the differences between the averages derived from weighted and unweighted data are very slight.

${ }^{[13]}$ It is not feasible to compute a measure of goodness of fit for the ordinal logit that takes into account complex sampling design in STATA. To give an indication of the fit, we computed the Pseudo R2 for unweighted specifications of these regression, which yields values of about $2 \%$.

Responses to this article can be read online at: http://www.ecologyandsociety.org/issues/responses. $\mathrm{php} / 9840$

\section{Acknowledgments:}

The authors are grateful for technical and financial support provided by ODI and the Building Resilience and Adaptation to Climate Extremes and Disasters (BRACED) programme funded by DFID. Financial support from the Economic and Social Research Council is also acknowledged. We thank Catherine Simonet, Paola Ballon, and three anonymous reviewers for their invaluable comments in helping to improve the manuscript. Finally, we are immensely grateful to Twaweza for its support in implementing the survey and its subsequent analysis.

\section{LITERATURE CITED}

Adger, N., H. Adams, L. Evans, S. O’Niell, and T. Quin. 2013. Human resilience to climate change and disasters: response from University of Exeter. The Royal Society, London, UK. [online] URL: https://royalsociety.org/ /media/policy/projects/resilienceclimate-change/parts1-20.pdf

Aldunce, P., R. Beilin, M. Howden, and J. Handmer. 2015. Resilience for disaster risk management in a changing climate: practitioners' frames and practices. Global Environmental Change 30:1-11. http://dx.doi.org/10.1016/j.gloenvcha.2014.10.010

Alexander, D. E. 2013. Resilience and disaster risk reduction: an etymological journey. Natural Hazards and Earth System Sciences 13(11):2707-2716. http://dx.doi.org/10.5194/nhess-13-2707-2013

Bahadur, A. V., K. Peters, E. Wilkinson, F. Pichon, K. Gray, and T. Tanner. 2015. The 3As: tracking resilience across BRACED. Working papers. Overseas Development Institute, London, UK. [online] URL: http://www.odi.org/sites/odi.org.uk/files/odi-assets/ publications-opinion-files/9812.pdf

Bahadur, A., and F. Pichon. 2017. Analysis of resilience measurement frameworks and approaches. Overseas Development Institute, London, UK. [online] URL: http://www.preventionweb. net/publications/view/52589

Basher, R. 2006. Global early warning systems for natural hazards: systematic and people-centred. Philosophical Transactions of the Royal Society of London A: Mathematical, Physical and Engineering Sciences 364(1845):2167-2182. http://dx.doi.org/10.1098/ rsta.2006.1819

Béné, C., R. M. Al-Hassan, O. Amarasinghe, P. Fong, J. Ocran, E. Onumah, R. Ratuniata, T. Van Tuyen, J. A. McGregor, and D. J. Mills. 2016a. Is resilience socially constructed? Empirical evidence from Fiji, Ghana, Sri Lanka, and Vietnam. Global Environmental Change 38:153-170. http://dx.doi.org/10.1016/j. gloenvcha.2016.03.005

Béné, C., T. Frankenberger, M. Langworthy, M. Mueller, and S. Martin. 2016b. The influence of subjective and psycho-socialfactors on people's resilience: conceptual framework and empirical evidence. Report prepared by the Technical Consortium, a project of the CGIAR. Technical Report Series No. 2: Strengthening the Evidence Base for Resilience in the Horn of Africa. International Livestock Research Institute (ILRI) and TANGO International publication, Nairobi, Kenya.

Béné, C., R. G. Wood, A. Newsham, and M. Davies. 2012. Resilience: new utopia or new tyranny? Reflection about the 
potentials and limits of the concept of resilience in relation to vulnerability reduction programmes. IDS Working Paper 2012 (405):1-61. http://dx.doi.org/10.1111/j.2040-0209.2012.00405.x

Berkes, F., J. Colding, and C. Folke, editors. 2002. Navigating social-ecological systems: building resilience for complexity and change. Cambridge University Press, Cambridge, UK. http://dx. doi.org/10.1017/CBO9780511541957

Bollettino, V., T. Alcayna, P. Dy, and P. Vinck. 2017. Introduction to socio-ecological resilience. In S. L. Cutter, editor. Oxford Encyclopedia of Natural Hazard Science. Oxford University Press, Oxford, UK. http://dx.doi.org/10.1093/acrefore/9780199389407.013.261

Buikstra, E., H. Ross, C. A. King, P. G. Baker, D. Hegney, K. McLachlan, and C. Rogers-Clark. 2010. The components of resilience-perceptions of an Australian rural community. Journal of Community Psychology 38(8):975-991. http://dx.doi. org/10.1002/jcop.20409

Connor, K. M., and J. R. T. Davidson. 2003. Development of a new resilience scale: the Connor-Davidson resilience scale (CDRISC). Depression and Anxiety 18(2):76-82. http://dx.doi. org/10.1002/da.10113

Constas, M., and C. Barrett. 2013. Principles of resilience measurement for food insecurity: metrics, mechanisms, and implementation issues. Expert consultation on resilience measurement related to food security. Food and Agricultural Organization and World Food Program, Rome, Italy.

Constas, M., J. Cisse, E. Knippenberg, and K. Downie. 2016. A focused review of methodologies to measure resilience: an analysis of conceptual presentations, indicators, and estimation procedures. Technical Report Series No 2: strengthening the evidence base for resilience in the Horn of Africa. Technical Consortium, a project of the CGIAR, International Livestock Research Institute (ILRI) and Charles H. Dyson School of Applied Economics and Management, College of Agriculture and Life Sciences, Cornell University, Ithaca, New York, USA.

Cutter, S. L., L. Barnes, M. Berry, C. Burton, E. Evans, E. Tate, and J. Webb. 2008. A place-based model for understanding community resilience to natural disasters. Global Environmental Change 18(4):598-606. http://dx.doi.org/10.1016/j.gloenvcha.2008.07.013

Deeming, C. 2013. Addressing the social determinants of subjective wellbeing: the latest challenge for social policy. Journal of Social Policy 42(03):541-565. http://dx.doi.org/10.1017/ $\underline{\mathrm{S} 0047279413000202}$

D'Errico, M., and S. Giuseppe. 2014. A dynamic analysis of resilience in Uganda. Food and Agriculture Organisation, Rome, Italy.

Elasha, B. O., N. G. Elhassan, H. Ahmed, and S. Zakieldin. 2005. Sustainable livelihood approach for assessing community resilience to climate change: case studies from Sudan. Assessments of Impacts and Adaptations of Climate Change Working Paper 17. URL: http://www.start.org/Projects/AIACC Project/working papers/ Working $\%$ 20Papers/AIACC_WP No017.pdf

Folke, C. 2006. Resilience: the emergence of a perspective for social-ecological systems analyses. Global Environmental Change 16(3):253-267. http://dx.doi.org/10.1016/j.gloenvcha.2006.04.002
Folke, C., S. R. Carpenter, B. Walker, M. Scheffer, T. Chapin, and J. Rockström. 2010. Resilience thinking: integrating resilience, adaptability and transformability. Ecology and Society 15(4):20. http://dx.doi.org/10.5751/ES-03610-150420

Food and Agriculture Organization (FAO). 2016. RIMA 2: resilience index measurement and analysis - II. FAO, Rome, Italy. [online] URL: http://www.fao.org/3/a-i5665e.pdf

Frankenberger, T. R., M. A. Constas, S. Nelson, and L. Starr. 2014. How NGOs approach resilience programming. International Food Policy Research Institute, Washington, D.C., USA.

Gaillard, J. C. 2010. Vulnerability, capacity and resilience: perspectives for climate and development policy. Journal of International Development 22(2):218-232. http://dx.doi.org/10.1002/ jid. 1675

Hedges, S., M. B. Mulder, S. James, and D. W. Lawson. 2016. Sending children to school: rural livelihoods and parental investment in education in northern Tanzania. Evolution and Human Behavior 37(2):142-151. http://dx.doi.org/10.1016/j. evolhumbehav.2015.10.001

Holling, C. S. 1973. Resilience and stability of ecological systems. Annual Review of Ecology and Systematics 4:1-23. http://dx.doi. org/10.1146/annurev.es.04.110173.000245

Jones, L. 2017. New methods in resilience measurement: early insights from a mobile phone panel survey in Myanmar using subjective tools. Building Resilience and Adaptation to Climate Extremes and Disasters (BRACED), Overseas Development Institute, London, UK, in press.

Jones, L., E. Ludi, and S. Levine. 2010. Towards a characterisation of adaptive capacity: a framework for analysing adaptive capacity at the local level. Overseas Development Institute, London, UK.

Jones, L., and T. Tanner. 2015. Measuring 'subjective resilience': using peoples' perceptions to quantify household resilience. Overseas Development Institute, London, UK. http://dx.doi. org/10.2139/ssrn.2643420

Jones, L., and T. Tanner. 2017. 'Subjective resilience': using perceptions to quantify household resilience to climate extremes and disasters. Regional Environmental Change 17:229-243. http:// dx.doi.org/10.1007/s10113-016-0995-2

Jorm, A. F., and S. M. Ryan. 2014. Cross-national and historical differences in subjective well-being. International Journal of Epidemiology 43(2):330-340. http://dx.doi.org/10.1093/ije/dyt188

Kates, R. W., W. R. Travis, and T. J. Wilbanks. 2012. Transformational adaptation when incremental adaptations to climate change are insufficient. Proceedings of the National Academy of Sciences 109(19):7156-7161. http://dx.doi.org/10.1073/ pnas. 1115521109

Leo, B., R. Morello, J. Mellon, T. Peixoto, and S. Davenport. 2015. Do mobile surveys work in poor countries? Working Paper 398. Center for Global Development, Washington, D.C., USA.

Levine, S. 2014. Assessing resilience: why quantification misses the point. Humanitarian Policy Group. Overseas Development Institute, London, UK. 
Lockwood, M., C. M. Raymond, E. Oczkowski, and M. Morrison. 2015. Measuring the dimensions of adaptive capacity: a psychometric approach. Ecology and Society 20(1):37. http:// dx.doi.org/10.5751/ES-07203-200137

Maguire, B., and S. Cartwright. 2008. Assessing a community's capacity to manage change: a resilience approach to social assessment. Australian Government Bureau of Rural Sciences, Canberra, Australia. [online] URL: http://www.tba.co.nz/tba-eq/ Resilience approach.pdf

Marshall, N. A. 2010. Understanding social resilience to climate variability in primary enterprises and industries. Global Environmental Change 20(1):36-43. http://dx.doi.org/10.1016/j. gloenvcha.2009.10.003

Marshall, N. A., and P. A. Marshall. 2007. Conceptualizing and operationalizing social resilience within commercial fisheries in northern Australia. Ecology and Society 12(1):1. http://dx.doi. org/10.5751/ES-01940-120101

Marusteri, M., and V. Bacarea. 2010. Comparing groups for statistical differences: how to choose the right statistical test? Biochemia Medica 20(1):15-32. http://dx.doi.org/10.11613/ BM.2010.004

Maxwell, D., M. Constas, T. Frankenberger, D. Klaus, and M. Mock. 2015. Qualitative data and subjective indicators for resilience measurement. Resilience Measurement Technical Working Group. Technical Series No. 4. Food Security Information Network, Rome, Italy. [online] URL: http://www. fsincop.net/fileadmin/user_upload/fsin/docs/resources/1_FSIN_TechnicalSeries 4.pdf

Miceli, R., I. Sotgiu, and M. Settanni. 2008. Disaster preparedness and perception of flood risk: a study in an alpine valley in Italy. Journal of Environmental Psychology 28 (2):164-173. http://dx.doi.org/10.1016/j.jenvp.2007.10.006

Miller, F., H. Osbahr, E. Boyd, F. Thomalla, S. Bharwani, G. Ziervogel, B. Walker, J. Birkmann, S. Van der Leeuw, J. Rockström, J. Hinkel, T. Downing, C. Folke, and D. Nelson. 2010. Resilience and vulnerability: complementary or conflicting concepts? Ecology and Society 15(3):11. http://dx.doi. org/10.5751/ES-03378-150311

Mills, M., K. Mutafoglu, V. M. Adams, C. Archibald, J. Bell, and J. X. Leon. 2016. Perceived and projected flood risk and adaptation in coastal southeast Queensland, Australia. Climatic Change 136(3-4):523-537. http://dx.doi.org/10.1007/s10584-016-1644$\mathrm{y}$

National Bureau of Statistics (NBS). 2013. 2012 Population and housing census: population distribution by administrative units. NBS and Office of Chief Government Statistician, Zanzibar, Dar es Salaam, Tanzania.

Nguyen, K. V., and H. James. 2013. Measuring resilience to floods: a case study in the Vietnamese Mekong River Delta. Ecology and Society 18(3):13. http://dx.doi.org/10.5751/ ES-05427-180313

Norris, F. H., S. P. Stevens, B. Pfefferbaum, K. F. Wyche, and R. L. Pfefferbaum. 2008. Community resilience as a metaphor, theory, set of capacities, and strategy for disaster readiness.
American Journal of Community Psychology 41(1-2):127-150. http://dx.doi.org/10.1007/s10464-007-9156-6

Odum, E. P. 1985. Trends expected in stressed ecosystems. BioScience 35:419-422. http://dx.doi.org/10.2307/1310021

Olsson, L., A. Jerneck, H. Thoren, J. Persson, and D. O’Byrne. 2015. Why resilience is unappealing to social science: theoretical and empirical investigations of the scientific use of resilience. Science Advances 1(4):e1400217. http://dx.doi.org/10.1126/ sciadv. 1400217

Organisation for Economic Co-operation and Development (OECD). 2013. OECD guidelines on measuring subjective wellbeing. OECD Publishing, Paris, France.

Schipper, E. L. F., and L. Langston. 2015. A comparative overview of resilience measurement frameworks: analysing indicators and approaches. ODI Working Paper 422. Overseas Development Institute, London, UK.

Seara, T., P. M. Clay, and L. L. Colburn. 2016. Perceived adaptive capacity and natural disasters: a fisheries case study. Global Environmental Change 38:49-57. http://dx.doi.org/10.1016/j. gloenvcha.2016.01.006

Sorensen, J. H. 2000. Hazard warning systems: review of 20 years of progress. Natural Hazards Review 1(2):119-125. http://dx.doi. org/10.1061/(ASCE)1527-6988(2000)1:2(119)

StataCorp. 2013. Suest: seemingly unrelated estimation. Pages Pages 2237-2254 in Stata Base reference manual. Release 13. Stata Press, College Station, Texas, USA.

Sundres, K., and M. L. Birnbaum, editors. 2003. Health disaster management: guidelines for evaluation and research in the Utstein style. Vol. I Conceptual framework of disasters. Prehospital and Disaster Medicine 17(Suppl. 3).

Tanner, T., D. Lewis, D. Wrathall, R. Bronen, N. Cradock-Henry, S. Huq, C. Lawless, R. Nawrotzki, V. Prasad, M. A. Rahman, R. Alaniz, K. King, K. McNamara, M. Nadiruzzaman, S. HenlyShepard, and F. Thomalla. 2015. Livelihood resilience in the face of climate change. Nature Climate Change 5(1):23-26. http://dx. doi.org/10.1038/nclimate2431

Twaweza. 2013. Sauti za Wananchi: collecting national data using mobile phones. Twaweza, Dar es Salaam, Tanzania. [online] URL: http://twaweza.org/uploads/files/SzW\%20Approach\%20Paper\%20FINAL. pdf

Twaweza. [date unknown]. Sample weights for Sauti za Wananchi. Twaweza, Dar es Salaam, Tanzania. [online] URL: http:// twaweza.org/uploads/files/SzW $\% 20$ baseline $\% 20$ weights $\% 20$ note. pdf

Twigg, J. 2009. Characteristics of a disaster-resilient community: a guidance note. Version 2. Tearfund, London, UK. [online] URL: http://discovery.ucl.ac.uk/1346086/1/1346086.pdf

United Nations. 2015a. Transforming our world: the 2030 agenda for sustainable development. United Nations, Washington, D.C., USA.

United Nations. 2015b. Adoption of the Paris Agreement. United Nations Framework Convention on Climate Change, Paris, France. 
United Nations. 2015c. Sendai framework for disaster risk reduction 2015 - 2030. United Nations Office for Disaster Risk Reduction, Geneva, Switzerland.

United States Agency for International Development (USAID). 2009. Community resilience: conceptual framework and measurement feed the future learning agenda. USAID, Rockville, Maryland, USA.

Walker, B., C. S. Holling, S. R. Carpenter, and A. Kinzig. 2004. Resilience, adaptability and transformability in social-ecological systems. Ecology and Society 9(2):5. http://dx.doi.org/10.5751/ ES-00650-090205

Walker, B. H., L. H. Gunderson, A. P. Kinzig, C. Folke, S. R. Carpenter, and L. Schultz. 2006. A handful of heuristics and some propositions for understanding resilience in social-ecological systems. Ecology and Society 11(1):13. http://dx.doi.org/10.5751/ ES-01530-110113

Walker, B. H., D. Ludwig, C. S. Holling, and R. M. Peterman. 1981. Stability of semi-arid savanna grazing systems. Journal of Ecology 69(2):473-498. http://dx.doi.org/10.2307/2259679

Weesie, J. 1999. Seemingly unrelated estimation and the clusteradjusted sandwich estimator. Stata Technical Bulletin 52:34-74. 


\section{Appendix 1. Supplementary materials.}

Fig. A1.1. Share of Tanzanians who perceive flooding to be a serious problem to their households or communities ${ }^{1}$.

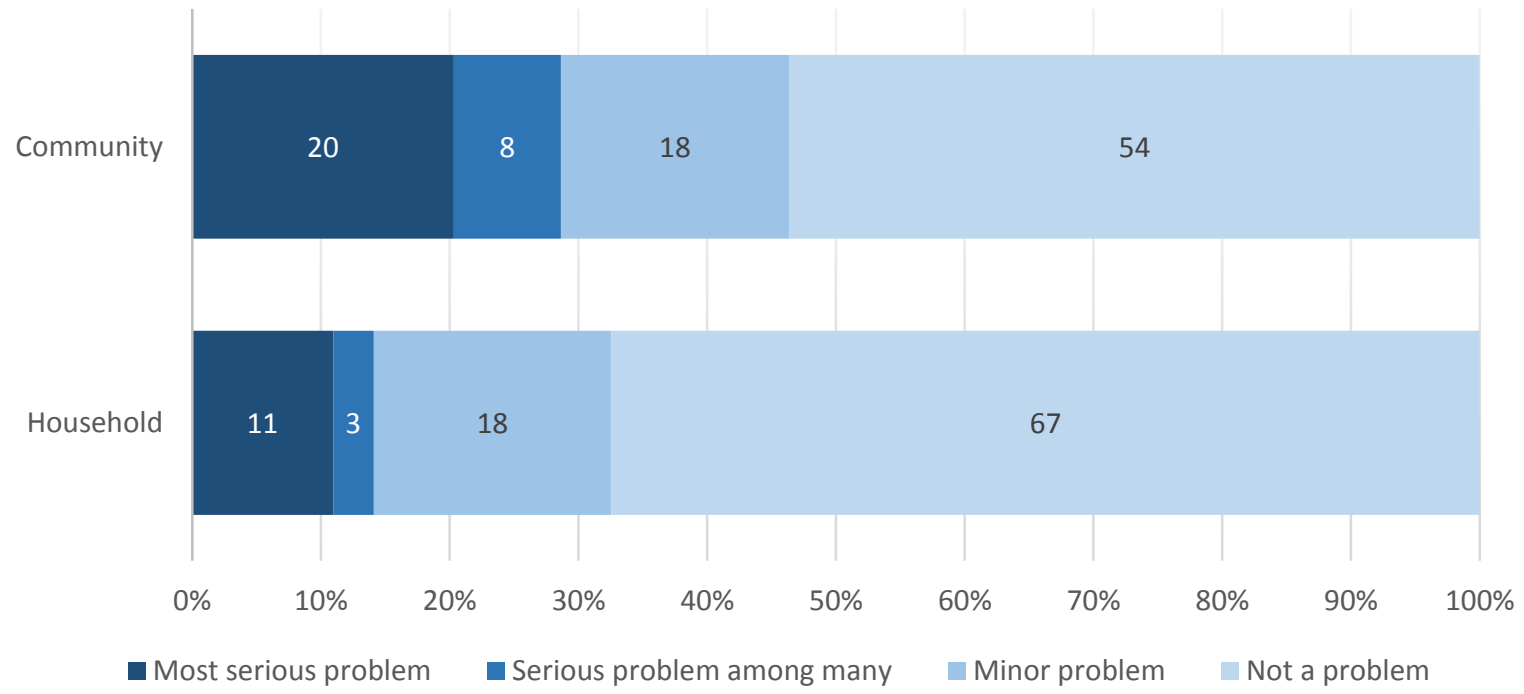

Fig. A1.2. Share of population who reported flooding to be a serious problem based on whether they had advance knowledge of recent flood.

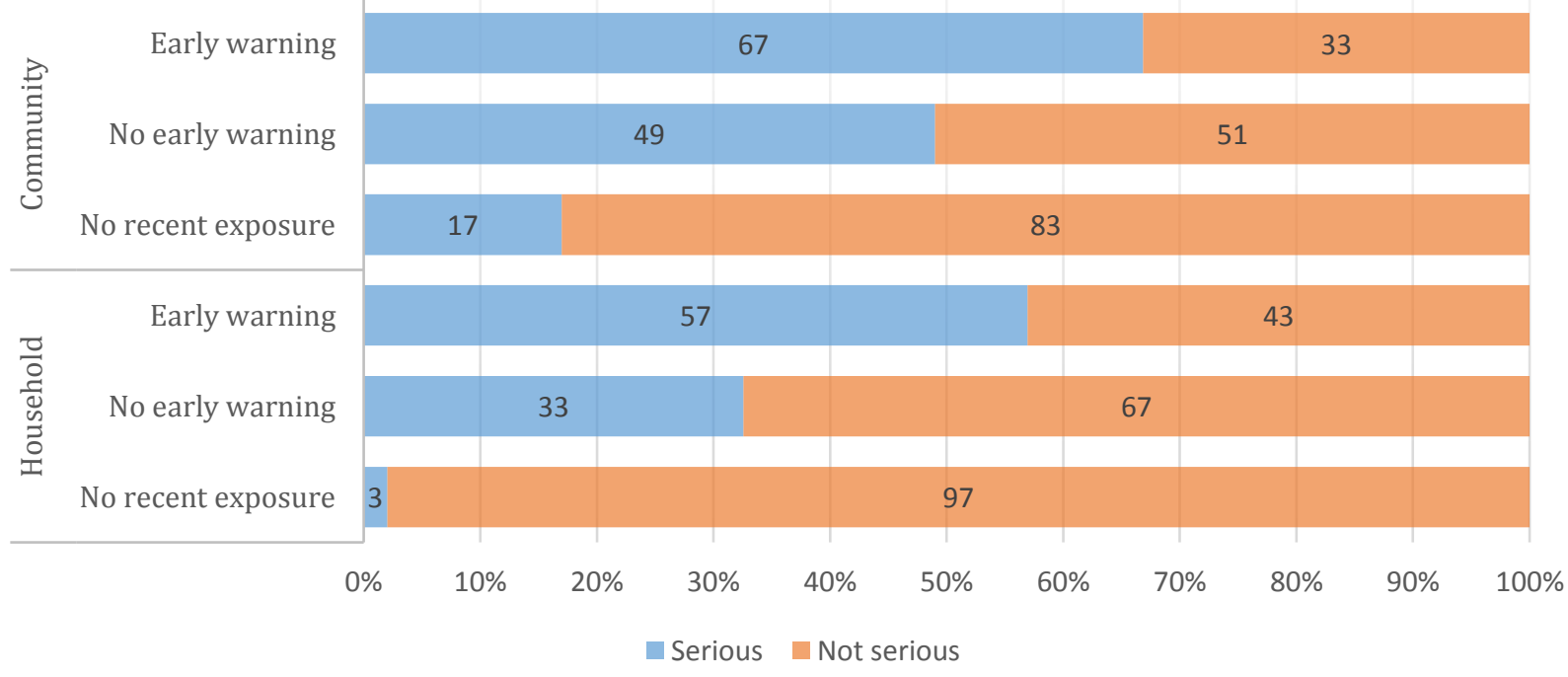

\footnotetext{
${ }^{1}$ Note that highlighted numbers may not add to 100 owing to rounding
} 
Fig. A1.3. Cross tabulations of the dichotomized dimensions of resilience-related capacities.

\begin{tabular}{l|ccc}
\hline \hline & Likely to prepare & Likely to recover & Likely to change \\
\hline Likely to prepare & -- & $53 \%$ & $58 \%$ \\
Unlikely to prepare & -- & $10 \%$ & $30 \%$ \\
Likely to recover & $74 \%$ & -- & $62 \%$ \\
Unlikely to recover & $21 \%$ & -- & $32 \%$ \\
Likely to change & $51 \%$ & $39 \%$ & -- \\
Unlikely to change & $24 \%$ & $16 \%$ & -- \\
\hline
\end{tabular}

Fig. A1.4. Spearman correlations between key measures of subjective resilience.

\begin{tabular}{l|rrr}
\hline & prepare & recover & change \\
\hline prepare & 1 & & \\
recover & $0.4519^{*}$ & 1 & \\
change & $0.3173^{*}$ & $0.2514^{*}$ & 1 \\
\hline
\end{tabular}

*Statistically significant at .05 level

Fig. A1.5. Results of principal components analysis.

a) Factor analysis

\begin{tabular}{l|rrrr}
\hline \hline Factor & Eigenvalue & Difference & Proportion & Cumulative \\
\hline Factor1 & 1.72815 & 0.96219 & 0.576 & 0.576 \\
Factor2 & 0.76595 & 0.26006 & 0.2553 & 0.8314 \\
Factor3 & 0.5059 & & 0.1686 & 1 \\
\hline
\end{tabular}


LR test: independent vs. saturated: $\operatorname{chi} 2(3)=534.60$ Prob $>$ chi $2=0.0000$

b) Factor loadings and unique variances (unrotated)

\begin{tabular}{l|rr}
\hline Variable & Factor 1 & Uniqueness \\
\hline prepare & 0.8212 & 0.3256 \\
recover & 0.7914 & 0.3736 \\
change & 0.6537 & 0.5726 \\
\hline
\end{tabular}


Table A1.1. Respondents' experience of flood in previous two years and whether they knew of it in advance.

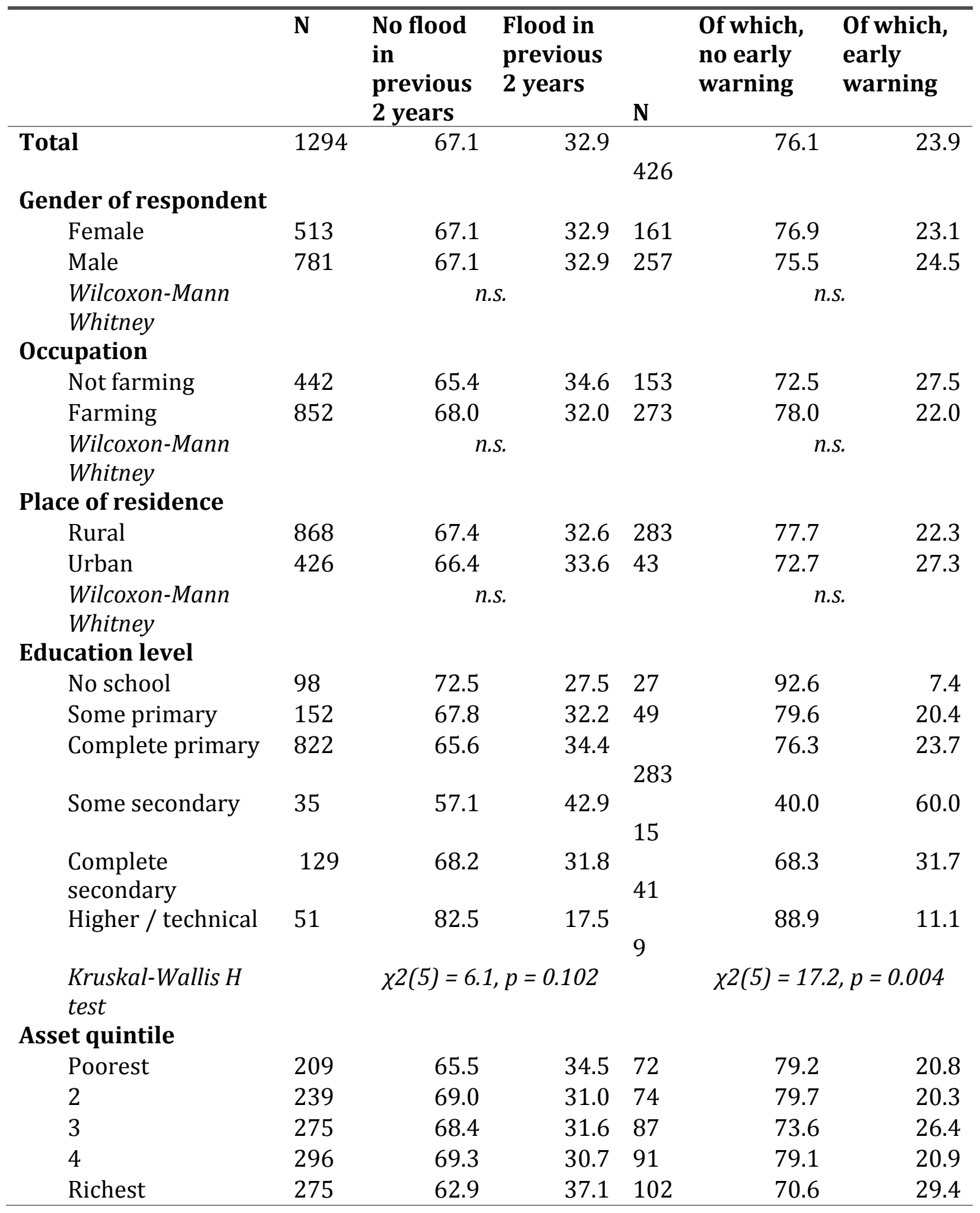




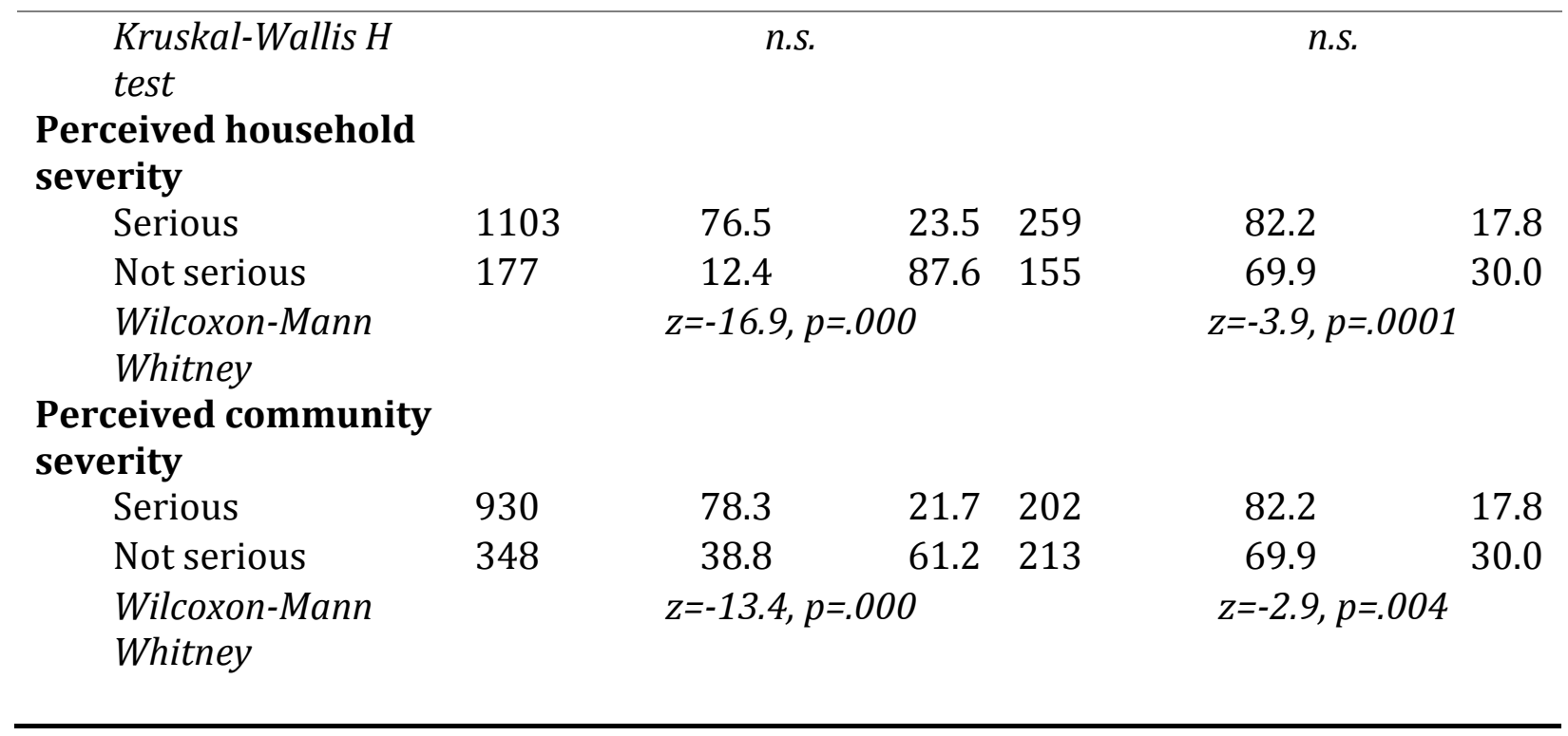


Table A1.2. Respondents' perceptions of flood severity among their households.

\begin{tabular}{|c|c|c|c|c|c|}
\hline Household & $\mathbf{N}$ & $\begin{array}{r}\text { Most } \\
\text { serious } \\
\text { problem }\end{array}$ & $\begin{array}{r}\text { Serious } \\
\text { problem } \\
\text { among } \\
\text { many }\end{array}$ & $\begin{array}{r}\text { Minor } \\
\text { problem }\end{array}$ & $\begin{array}{r}\text { Not a } \\
\text { problem }\end{array}$ \\
\hline Total & $\begin{array}{r}128 \\
0\end{array}$ & 10.8 & 3.0 & 17.9 & 68.3 \\
\hline \multicolumn{6}{|l|}{ Gender of respondent } \\
\hline Female & 512 & 11.1 & 3.1 & 16.6 & 69.1 \\
\hline Male & 768 & 10.5 & 3.0 & 18.7 & 67.7 \\
\hline $\begin{array}{l}\text { Wilcoxon-Mann } \\
\text { Whitney }\end{array}$ & & \multicolumn{4}{|c|}{ n.s. } \\
\hline \multicolumn{6}{|l|}{ Occupation } \\
\hline Not farming & 440 & 10.7 & 2.5 & 18.9 & 67.9 \\
\hline Farming & 840 & 10.8 & 3.3 & 17.4 & 68.4 \\
\hline $\begin{array}{l}\text { Wilcoxon-Mann } \\
\text { Whitney }\end{array}$ & & \multicolumn{4}{|c|}{ n.s. } \\
\hline \multicolumn{6}{|l|}{ Place of residence } \\
\hline Rural & 859 & 10.9 & 2.9 & 17.1 & 69.0 \\
\hline Urban & 421 & 10.4 & 3.3 & 19.5 & 66.7 \\
\hline $\begin{array}{l}\text { Wilcoxon-Mann } \\
\text { Whitney }\end{array}$ & & \multicolumn{4}{|c|}{ n.s. } \\
\hline \multicolumn{6}{|l|}{ Education level } \\
\hline No school & 98 & 13.3 & 1.0 & 20.4 & 65.3 \\
\hline Some primary & 149 & 12.7 & 1.3 & 14.1 & 71.8 \\
\hline Complete primary & 811 & 10.1 & 3.9 & 17.8 & 68.2 \\
\hline Some secondary & 35 & 11.4 & 0 & 25.7 & 62.9 \\
\hline Complete secondary & 129 & 12.4 & 2.3 & 20.2 & 65.1 \\
\hline Higher / technical & 51 & 5.9 & 2.0 & 15.7 & 76.5 \\
\hline Kruskal-Wallis H test & & \multicolumn{4}{|c|}{ n.s. } \\
\hline \multicolumn{6}{|l|}{ Asset quintile } \\
\hline Poorest & 207 & 14.5 & 2.4 & 17.8 & 65.2 \\
\hline 2 & 235 & 10.2 & 4.3 & 18.3 & 67.2 \\
\hline 3 & 271 & 10.0 & 4.1 & 18.8 & 67.2 \\
\hline 4 & 292 & 8.2 & 1.4 & 16.1 & 74.3 \\
\hline Richest & 275 & 12.0 & 3.3 & 18.5 & 66.2 \\
\hline Kruskal-Wallis H test & & \multicolumn{4}{|c|}{ n.s. } \\
\hline \multicolumn{6}{|l|}{ Flood experience } \\
\hline $\begin{array}{l}\text { No flood in last } 2 \\
\text { years }\end{array}$ & 866 & 1.8 & .69 & 12.0 & 85.4 \\
\hline $\begin{array}{l}\text { Flood in last two } \\
\text { years }\end{array}$ & 414 & 29.5 & 8.0 & 30.2 & 32.4 \\
\hline
\end{tabular}


Wilcoxon-Mann

$z=20.1, p=.000$

Whitney

Early warning of flood (among flood-

exposed)

No early warning

$314 \quad 25.2$

7.0

30.2

37.6

Early warning

100

43.0

11.0

30.0

16.0

Wilcoxon-Mann

$z=4.5, p=.000$

Whitney 
Table A1.3. Respondents' perceptions of flood severity for their communities.

\begin{tabular}{|c|c|c|c|c|c|}
\hline Community & $\mathbf{N}$ & $\begin{array}{l}\text { Most serious } \\
\text { problem }\end{array}$ & $\begin{array}{l}\text { Serious problem } \\
\text { among many }\end{array}$ & $\begin{array}{l}\text { Minor } \\
\text { problem }\end{array}$ & $\begin{array}{r}\text { Not a } \\
\text { problem }\end{array}$ \\
\hline Total & 1278 & 19.9 & 7.4 & 16.9 & 55.9 \\
\hline Female & 511 & 20.5 & 8.4 & 16.4 & 54.6 \\
\hline Male & 767 & 19.4 & 6.6 & 17.2 & 56.7 \\
\hline $\begin{array}{l}\text { Wilcoxon-Mann } \\
\text { Whitney }\end{array}$ & & \multicolumn{4}{|c|}{ n.s. } \\
\hline \multicolumn{6}{|l|}{ Occupation } \\
\hline Not farming & 439 & 20.3 & 7.5 & 17.5 & 54.7 \\
\hline Farming & 839 & 19.7 & 7.3 & 16.6 & 56.5 \\
\hline $\begin{array}{l}\text { Wilcoxon-Mann } \\
\text { Whitney }\end{array}$ & & \multicolumn{4}{|c|}{ n.s. } \\
\hline \multicolumn{6}{|l|}{ Place of residence } \\
\hline Rural & 857 & 19.4 & 7.0 & 17.0 & 56.6 \\
\hline Urban & 421 & 20.9 & 8.1 & 16.6 & 54.4 \\
\hline $\begin{array}{l}\text { Wilcoxon-Mann } \\
\text { Whitney }\end{array}$ & & \multicolumn{4}{|c|}{ n.s. } \\
\hline \multicolumn{6}{|l|}{ Education level } \\
\hline No school & 98 & 22.4 & 13.3 & 14.3 & 50.0 \\
\hline Some primary & 147 & 22.4 & 4.1 & 17.7 & 55.8 \\
\hline Complete primary & 812 & 20.1 & 7.3 & 16.6 & 56.0 \\
\hline Some secondary & 35 & 17.1 & 5.7 & 22.9 & 54.3 \\
\hline Complete secondary & 129 & 19.4 & 5.4 & 21.7 & 53.5 \\
\hline Higher / technical & 50 & 8.0 & 10.0 & 10.0 & 72.0 \\
\hline Kruskal-Wallis H test & & \multicolumn{4}{|c|}{ n.s. } \\
\hline \multicolumn{6}{|l|}{ Asset quintile } \\
\hline Poorest & 206 & 24.3 & 8.2 & 19.9 & 47.6 \\
\hline 2 & 235 & 23.0 & 8.5 & 14.0 & 54.5 \\
\hline 3 & 271 & 19.9 & 6.6 & 16.6 & 56.8 \\
\hline 4 & 292 & 14.7 & 4.1 & 17.5 & 63.7 \\
\hline Richest & 274 & 19.3 & 9.3 & 16.8 & 54.0 \\
\hline Kruskal-Wallis H test & & \multicolumn{4}{|c|}{$\chi^{2}(4)=15.6, p=0.004$} \\
\hline \multicolumn{6}{|l|}{ Flood experience } \\
\hline $\begin{array}{l}\text { No flood in last } 2 \\
\text { years }\end{array}$ & 863 & 10.9 & 4.7 & 11.4 & 73.0 \\
\hline $\begin{array}{l}\text { Flood in last two } \\
\text { years }\end{array}$ & 415 & 38.5 & 12.8 & 28.4 & 20.2 \\
\hline $\begin{array}{l}\text { Wilcoxon-Mann } \\
\text { Whitney }\end{array}$ & & & $z=17.5, p=.00$ & & \\
\hline \multicolumn{6}{|c|}{ Early warning of flood (among flood-exposed) } \\
\hline No early warning & 315 & 33.3 & 14.0 & 28.2 & 24.4 \\
\hline
\end{tabular}


Early warning

Wilcoxon-Mann

Whitney
100

55.0

9.0

29.0

7.0

$$
z=4.2, p=.000
$$


Table A1.4. Perceived capacity to be prepared for an extreme flood by respondent characteristics.

\begin{tabular}{|c|c|c|c|c|c|}
\hline & & $\begin{array}{r}\text { Extremely } \\
\text { likely }\end{array}$ & $\begin{array}{l}\text { Very } \\
\text { likely }\end{array}$ & $\begin{array}{r}\text { Not very } \\
\text { likely }\end{array}$ & $\begin{array}{r}\text { Not at all } \\
\text { likely }\end{array}$ \\
\hline Total & $\begin{array}{r}129 \\
4\end{array}$ & 17.0 & 16.2 & 34.7 & 32.2 \\
\hline \multicolumn{6}{|l|}{ Gender of respondent } \\
\hline Female & 513 & 16.4 & 16.8 & 35.5 & 31.4 \\
\hline Male & 781 & 17.4 & 15.8 & 34.2 & 32.7 \\
\hline Wilcoxon-Mann Whitney & & \multicolumn{4}{|c|}{ n.s. } \\
\hline \multicolumn{6}{|l|}{ Occupation } \\
\hline Not farming & 442 & 16.1 & 18.6 & 34.8 & 30.5 \\
\hline Farming & 852 & 17.5 & 14.9 & 34.6 & 33.0 \\
\hline Wilcoxon-Mann Whitney & & \multicolumn{4}{|c|}{ n.s. } \\
\hline \multicolumn{6}{|l|}{ Place of residence } \\
\hline Rural & 868 & 16.8 & 15.3 & 36.8 & 31.1 \\
\hline Urban & 426 & 17.4 & 17.8 & 30.5 & 34.3 \\
\hline Wilcoxon-Mann Whitney & & \multicolumn{4}{|c|}{ n.s. } \\
\hline \multicolumn{6}{|l|}{ Education level } \\
\hline No school & 98 & 14.3 & 10.2 & 41.8 & 33.7 \\
\hline Some primary & 152 & 14.5 & 15.1 & 36.8 & 33.6 \\
\hline Complete primary & 822 & 17.5 & 17.3 & 32.9 & 32.4 \\
\hline Some secondary & 35 & 8.6 & 22.9 & 31.4 & 37.1 \\
\hline $\begin{array}{l}\text { Complete secondary } \\
\text { school }\end{array}$ & 129 & 17.8 & 15.5 & 34.1 & 32.6 \\
\hline Higher / technical & 51 & 25.5 & 11.8 & 47.1 & 15.7 \\
\hline \multicolumn{2}{|l|}{ Asset quintile } & \multicolumn{4}{|c|}{ n.s. } \\
\hline \multirow[t]{4}{*}{ Poorest } & 209 & 13.4 & 13.4 & 35.9 & 37.3 \\
\hline & 239 & 21.3 & 12.6 & 33.5 & 32.6 \\
\hline & 275 & 15.6 & 19.3 & 32.7 & 32.4 \\
\hline & 296 & 16.2 & 16.6 & 37.5 & 29.7 \\
\hline Richest & 275 & 18.2 & 17.8 & 33.8 & 30.2 \\
\hline Kruskal-Wallis H test & & \multicolumn{4}{|c|}{ n.s. } \\
\hline \multicolumn{6}{|l|}{ Flood experience } \\
\hline $\begin{array}{l}\text { No flood in last } 2 \\
\text { years }\end{array}$ & 868 & 16.9 & 15.7 & 32.1 & 35.3 \\
\hline $\begin{array}{l}\text { Flood in last two } \\
\text { years }\end{array}$ & 426 & 17.1 & 17.1 & 39.9 & 25.8 \\
\hline Wilcoxon-Mann Whitney & & & $z=2.2$ & 027 & \\
\hline \multicolumn{6}{|c|}{$\begin{array}{l}\text { Early warning of flood (among flood- } \\
\text { exposed) }\end{array}$} \\
\hline No early warning & 324 & 15.4 & 14.8 & 42.6 & 27.2 \\
\hline
\end{tabular}




\begin{tabular}{|c|c|c|c|c|c|}
\hline Early warning & 102 & 22.6 & 24.5 & 31.4 & 21.6 \\
\hline \multicolumn{3}{|c|}{ Wilcoxon-Mann Whitney } & \multicolumn{3}{|c|}{$z=-2.5, p=.012$} \\
\hline \multicolumn{6}{|c|}{ Perceived severity of flooding to household } \\
\hline Not serious & $\begin{array}{r}110 \\
3\end{array}$ & 16.4 & 16.0 & 35.2 & 32.5 \\
\hline Serious & 177 & 19.8 & 16.4 & 34.5 & 29.4 \\
\hline \multicolumn{3}{|c|}{ Wilcoxon-Mann Whitney } & \multicolumn{2}{|c|}{ n.s. } & \\
\hline \multicolumn{6}{|c|}{$\begin{array}{l}\text { Perceived severity of flooding to } \\
\text { community }\end{array}$} \\
\hline Not serious & 930 & 14.4 & 17.1 & 35.6 & 32.9 \\
\hline Serious & 348 & 23.6 & 12.6 & 33.6 & 30.2 \\
\hline \multicolumn{3}{|c|}{ Wilcoxon-Mann Whitney } & \multicolumn{2}{|c|}{$z=2.1, p=.037$} & \\
\hline
\end{tabular}


Table A1.5. Perceived capacity to be recover fully from an extreme flood by respondent characteristics.

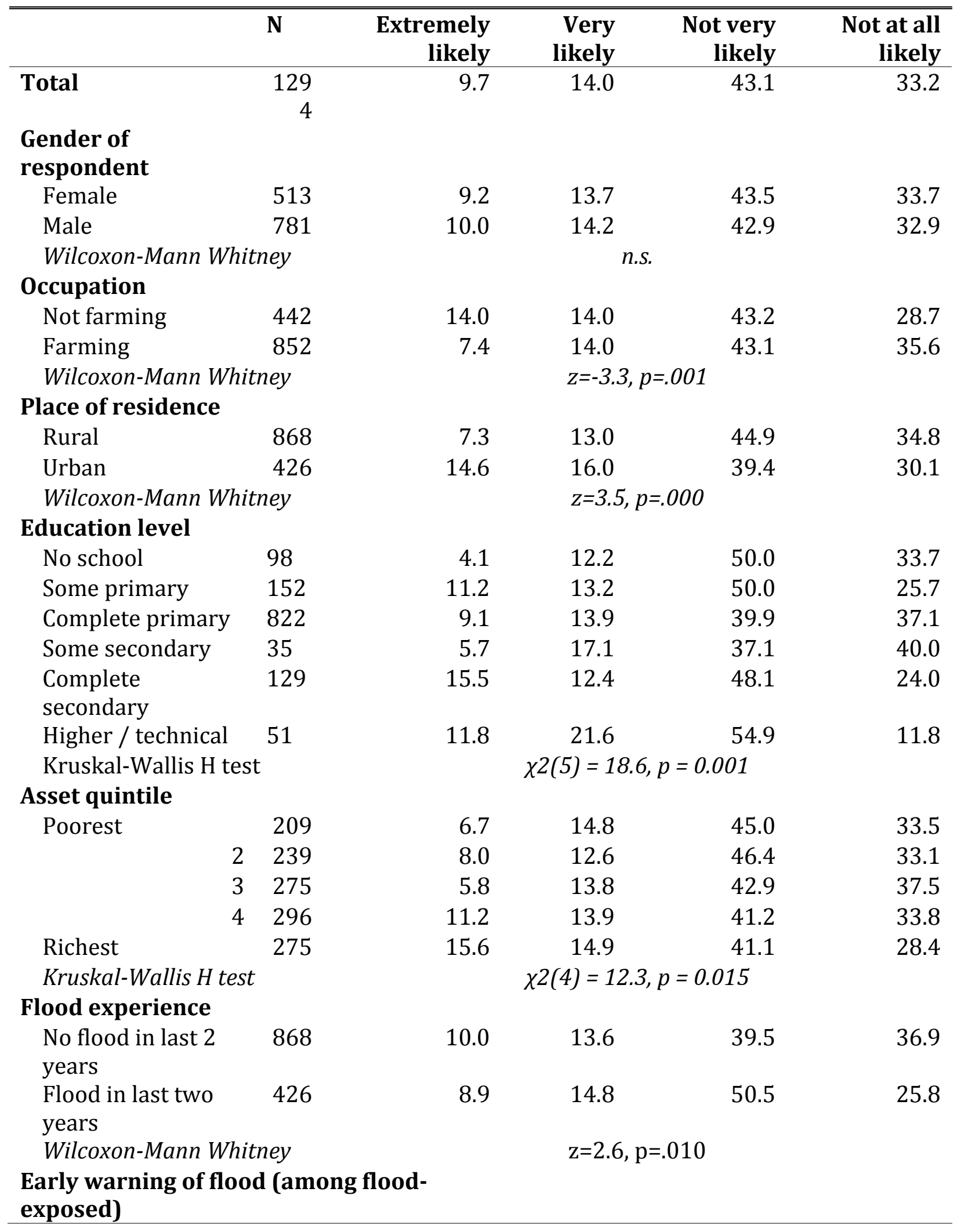




\begin{tabular}{|c|c|c|c|c|c|}
\hline No early warning & 324 & 6.8 & 13.6 & 51.5 & 28.1 \\
\hline Early warning & 102 & 15.7 & 18.6 & 47.1 & 18.6 \\
\hline \multicolumn{3}{|c|}{ Wilcoxon-Mann Whitney } & \multicolumn{3}{|c|}{$\mathrm{z}=3.0, \mathrm{p}=.002$} \\
\hline \multicolumn{6}{|c|}{$\begin{array}{l}\text { Perceived severity of flooding to } \\
\text { household }\end{array}$} \\
\hline Not serious & $\begin{array}{r}110 \\
3\end{array}$ & 9.5 & 13.9 & 42.1 & 34.5 \\
\hline Serious & 177 & 9.6 & 13.6 & 50.9 & 26.0 \\
\hline \multicolumn{3}{|c|}{ Wilcoxon-Mann Whitney } & \multicolumn{2}{|c|}{ n.s. } & \\
\hline \multicolumn{6}{|c|}{$\begin{array}{l}\text { Perceived severity of flooding to } \\
\text { community }\end{array}$} \\
\hline Not serious & 930 & 10.1 & 12.9 & 41.7 & 35.3 \\
\hline Serious & 348 & 7.8 & 16.1 & 47.7 & 28.5 \\
\hline \multicolumn{3}{|c|}{ Wilcoxon-Mann Whitney } & \multicolumn{2}{|c|}{ n.s. } & \\
\hline
\end{tabular}


Table A1.6. Perceived capacity to change livelihood strategy by respondent characteristic.

\begin{tabular}{|c|c|c|c|c|c|}
\hline & $\mathbf{N}$ & $\begin{array}{r}\text { Extremely } \\
\text { likely }\end{array}$ & $\begin{array}{r}\text { Very } \\
\text { likely }\end{array}$ & $\begin{array}{r}\text { Not very } \\
\text { likely }\end{array}$ & $\begin{array}{r}\text { Not at all } \\
\text { likely }\end{array}$ \\
\hline Total & $\begin{array}{r}129 \\
4\end{array}$ & 9.7 & 14.0 & 43.1 & 33.2 \\
\hline \multicolumn{6}{|l|}{$\begin{array}{l}\text { Gender of } \\
\text { respondent }\end{array}$} \\
\hline Female & 513 & 9.2 & 13.7 & 43.5 & 33.7 \\
\hline Male & 781 & 10.0 & 14.2 & 42.9 & 32.9 \\
\hline \multicolumn{3}{|c|}{ Wilcoxon-Mann Whitney } & \multicolumn{2}{|c|}{ n.s. } & \\
\hline \multicolumn{6}{|c|}{ Occupation } \\
\hline Not farming & 442 & 14.0 & 14.0 & 43.2 & 28.7 \\
\hline Farming & 852 & 7.4 & 14.0 & 43.1 & 35.6 \\
\hline \multicolumn{2}{|c|}{ Wilcoxon-Mann Whitney } & \multicolumn{4}{|c|}{ n.s. } \\
\hline \multicolumn{6}{|c|}{ Place of residence } \\
\hline Rural & 868 & 7.3 & 13.0 & 44.9 & 34.8 \\
\hline Urban & 426 & 14.6 & 16.0 & 39.4 & 30.1 \\
\hline \multicolumn{2}{|c|}{ Wilcoxon-Mann Whitney } & \multicolumn{4}{|c|}{ n.s. } \\
\hline \multicolumn{6}{|c|}{ Education level } \\
\hline No school & 98 & 4.1 & 12.2 & 50.0 & 33.7 \\
\hline Some primary & 152 & 11.2 & 13.2 & 50.0 & 25.7 \\
\hline Complete primary & 822 & 9.1 & 13.9 & 39.9 & 37.1 \\
\hline Some secondary & 35 & 5.7 & 17.1 & 37.1 & 40.0 \\
\hline $\begin{array}{l}\text { Complete } \\
\text { secondary }\end{array}$ & 129 & 15.5 & 12.4 & 48.1 & 24.0 \\
\hline Higher / technical & 51 & 11.8 & 21.6 & 54.9 & 11.8 \\
\hline Kruskal-Wallis H tes & & \multicolumn{4}{|c|}{ n.s. } \\
\hline \multicolumn{6}{|l|}{ Asset quintile } \\
\hline \multirow[t]{4}{*}{ Poorest } & 209 & 6.7 & 14.8 & 45.0 & 33.5 \\
\hline & 239 & 8.0 & 12.6 & 46.4 & 33.1 \\
\hline & 275 & 5.8 & 13.8 & 42.9 & 37.5 \\
\hline & 296 & 11.2 & 13.9 & 41.2 & 33.8 \\
\hline Richest & 275 & 15.6 & 14.9 & 41.1 & 28.4 \\
\hline \multicolumn{2}{|c|}{ Kruskal-Wallis H test } & \multicolumn{4}{|c|}{$\chi^{2}(4)=14.3, p=0.006$} \\
\hline \multicolumn{6}{|l|}{ Flood experience } \\
\hline $\begin{array}{l}\text { No flood in last } 2 \\
\text { years }\end{array}$ & 868 & 10.0 & 13.6 & 39.5 & 36.9 \\
\hline $\begin{array}{l}\text { Flood in last two } \\
\text { years }\end{array}$ & 426 & 8.9 & 14.8 & 50.5 & 25.8 \\
\hline Wilcoxon-Mann Whi & ney & & $z=2.0$, & 41 & \\
\hline \multicolumn{6}{|c|}{$\begin{array}{l}\text { Early warning of flood (among flood- } \\
\text { exposed) }\end{array}$} \\
\hline No early warning & 324 & 6.8 & 13.6 & 51.5 & 28.1 \\
\hline
\end{tabular}




\begin{tabular}{|c|c|c|c|c|c|}
\hline Early warning & 102 & 15.7 & 18.6 & 47.1 & 18.6 \\
\hline \multicolumn{3}{|c|}{ Wilcoxon-Mann Whitney } & \multicolumn{3}{|c|}{$\mathrm{z}=3.7, \mathrm{p}=.000$} \\
\hline \multicolumn{6}{|c|}{$\begin{array}{l}\text { Perceived severity of flooding to } \\
\text { household }\end{array}$} \\
\hline Not serious & $\begin{array}{r}110 \\
3\end{array}$ & 9.5 & 13.9 & 42.1 & 34.5 \\
\hline Serious & 177 & 9.6 & 13.6 & 50.9 & 26.0 \\
\hline \multicolumn{3}{|c|}{ Wilcoxon-Mann Whitney } & \multicolumn{3}{|c|}{$z=1.9, p=.054$} \\
\hline \multicolumn{6}{|c|}{$\begin{array}{l}\text { Perceived severity of flooding to } \\
\text { community }\end{array}$} \\
\hline Not serious & 930 & 10.1 & 12.9 & 41.7 & 35.3 \\
\hline Serious & 348 & 7.8 & 16.1 & 47.7 & 28.5 \\
\hline \multicolumn{3}{|c|}{ Wilcoxon-Mann Whitney } & \multicolumn{3}{|c|}{$z=4.9, p=.000$} \\
\hline
\end{tabular}


Table A1.7. Seemingly unrelated ordinal logit regressions on resilience-related capacities.

\begin{tabular}{|c|c|c|c|c|c|c|c|c|c|}
\hline & \multicolumn{3}{|c|}{ Prepare } & \multicolumn{3}{|c|}{ Recover } & \multicolumn{3}{|c|}{ Change } \\
\hline & coeff. & s.e. & & coeff. & s.e. & & coeff. & s.e. & \\
\hline Age & -0.042 & 0.023 & * & 0.008 & 0.029 & & 0.023 & 0.023 & \\
\hline Age*Age & 0.001 & 0.000 & ** & 0.000 & 0.000 & & 0.000 & 0.000 & \\
\hline HH size & -0.022 & 0.030 & & 0.057 & 0.030 & * & -0.011 & 0.026 & \\
\hline \multicolumn{10}{|c|}{ Gender of respondent ( $0=$ Female) } \\
\hline Male & -0.213 & 0.137 & & -0.089 & 0.139 & & 0.031 & 0.117 & \\
\hline \multicolumn{10}{|c|}{ Education (0=No schooling) } \\
\hline $\begin{array}{l}\text { Some } \\
\text { primary }\end{array}$ & -0.101 & 0.255 & & 0.325 & 0.252 & & -0.011 & 0.268 & \\
\hline $\begin{array}{l}\text { Complete } \\
\text { primary }\end{array}$ & 0.284 & 0.209 & & 0.068 & 0.220 & & 0.173 & 0.223 & \\
\hline $\begin{array}{l}\text { Some } \\
\text { secondary }\end{array}$ & -0.217 & 0.365 & & -0.209 & 0.435 & & -0.289 & 0.400 & \\
\hline $\begin{array}{l}\text { Complete } \\
\text { secondary }\end{array}$ & 0.190 & 0.298 & & 0.446 & 0.311 & & 0.313 & 0.294 & \\
\hline $\begin{array}{l}\text { Higher / } \\
\text { technical }\end{array}$ & 0.619 & 0.323 & $*$ & 0.790 & 0.330 & $* *$ & -0.221 & 0.385 & \\
\hline \multicolumn{10}{|c|}{ Occupation ( $0=$ not farmer) } \\
\hline Farmer & 0.015 & 0.160 & & -0.196 & 0.159 & & 0.023 & 0.164 & \\
\hline \multicolumn{10}{|c|}{ Residence ( $0=$ rural) } \\
\hline Urban & -0.149 & 0.178 & & 0.233 & 0.194 & & -0.012 & 0.154 & \\
\hline \multicolumn{10}{|c|}{ Asset quintile ( $0=$ poorest $)$} \\
\hline 2 & 0.275 & 0.197 & & -0.008 & 0.192 & & 0.318 & 0.171 & * \\
\hline 3 & 0.295 & 0.195 & & -0.238 & 0.206 & & 0.387 & 0.186 & ** \\
\hline 4 & 0.260 & 0.200 & & -0.003 & 0.217 & & 0.472 & 0.204 & $* *$ \\
\hline $\mathbf{5}$ & 0.236 & 0.273 & & -0.141 & 0.281 & & 0.623 & 0.237 & $* * *$ \\
\hline \multicolumn{10}{|c|}{ Early warning of last flood ( $0=$ no flood experience) } \\
\hline No & 0.089 & 0.141 & & 0.175 & 0.127 & & -0.174 & 0.131 & \\
\hline Yes & 0.878 & 0.255 & $* * *$ & 1.098 & 0.251 & $* * *$ & 0.610 & 0.219 & *** \\
\hline \multicolumn{10}{|c|}{ Believes flooding serious problem for community ( $0=$ not problematic) } \\
\hline Serious & 0.069 & 0.161 & & -0.050 & 0.143 & & 0.508 & 0.142 & $* * *$ \\
\hline $\mathbf{N}$ & & & & & 1271 & & & & \\
\hline Prob $>F$ & & 030 & & & 0.001 & & & 0.000 & \\
\hline
\end{tabular}

